\title{
SURFACE-WATER QUALITY AT FIXED SITES IN THE WESTERN LAKE MICHIGAN DRAINAGES, WISCONSIN AND MICHIGAN, AND THE EFFECTS OF NATURAL AND HUMAN FACTORS, 1993-95
}

By Kevin D. Richards, Daniel J. Sullivan, and Jana S. Stewart

U.S. GEOLOGICAL SURVEY

Water-Resources Investigations Report 97-4208

NATIONAL WATER-QUALITY ASSESSMENT PROGRAM WESTERN LAKE MICHIGAN DRAINAGES

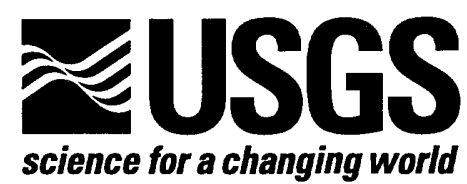

Middleton, Wisconsin 1998 


\title{
U.S. DEPARTMENT OF THE INTERIOR BRUCE BABBITT, Secretary
}

\author{
U.S. GEOLOGICAL SURVEY \\ Thomas J. Casadevall, Acting Director
}

The use of firm, trade, and brand names in this report is for identification purposes only and does not constitute endorsement by the U.S. Geological Survey.

For additional information write to:

Copies of this report can be purchased from:

District Chief

U.S. Geological Survey

8505 Research Way

Middleton, WI 53562-3586
U.S. Geological Survey

Branch of Information Services

Box 25286

Denver, .CO 80225-0286 


\section{FOREWORD}

The mission of the U.S. Geological Survey (USGS) is to assess the quantity and quality of the earth resources of the Nation and to provide information that will assist resource managers and policymakers at Federal, State, and local levels in making sound decisions. Assessment of water-quality conditions and trends is an important part of this overall mission.

One of the greatest challenges faced by waterresources scientists is acquiring reliable information that will guide the use and protection of the Nation's water resources. That challenge is being addressed by Federal, State, interstate, and local water-resource agencies and by many academic institutions. These organizations are collecting water-quality data for a host of purposes that include compliance with permits and water-supply standards; development of remediation plans for specific contamination problems; operational decisions on industrial, wastewater, or watersupply facilities; and research on factors that affect water quality. An additional need for water-quality information is to provide a basis on which regionaland national-level policy decisions can be based. Wise decisions must be based on sound information. As a society we need to know whether certain types of water-quality problems are isolated or ubiquitous, whether there are significant differences in conditions among regions, whether the conditions are changing over time, and why these conditions change from place to place and over time. The information can be used to help determine the efficacy of existing waterquality policies and to help analysts determine the need for and likely consequences of new policies.

To address these needs, the U.S. Congress appropriated funds in 1986 for the USGS to begin a pilot program in seven project areas to develop and refine the National Water-Quality Assessment (NAWQA) Program. In 1991, the USGS began full implementation of the program. The NAWQA Program builds upon an existing base of water-quality studies of the USGS, as well as those of other Federal, State, and local agencies. The objectives of the NAWQA Program are to

- Describe current water-quality conditions for a large part of the Nation's freshwater streams, rivers, and aquifers.
- Describe how water quality is changing over time.

- Improve understanding of the primary natural and human factors that affect water-quality conditions.

This information will help support the development and evaluation of management, regulatory, and monitoring decisions by other Federal, State, and local agencies to protect, use, and enhance water resources.

The goals of the NAWQA Program are being achieved through ongoing and proposed investigations of 59 of the Nation's most important river basins and aquifer systems, which are referred to as Study Units. These Study Units are distributed throughout the Nation and cover a diversity of hydrogeologic settings. More than two-thirds of the Nation's freshwater use occurs within the 59 Study Units, and more than twothirds of the people served by public water-supply systems live within their boundaries.

National synthesis of data analysis, based on aggregation of comparable information obtained from the Study Units, is a major component of the program. This effort focuses on selected water-quality topics using nationally consistent information. Comparative studies will explain differences and similarities in observed water-quality conditions among study areas and will identify changes and trends and their causes. The first topics addressed by the national synthesis are pesticides, nutrients, volatile organic compounds, and aquatic biology. Discussions on these and other waterquality topics will be published in periodic summaries of the quality of the Nation's ground water and surface water as the information becomes available.

This report is an element of the comprehensive body of information developed as part of the NAWQA Program. The program depends heavily on the advice, cooperation, and information from many Federal, State, interstate, Tribal, and local agencies and the public. The assistance and suggestions of all are greatly appreciated.

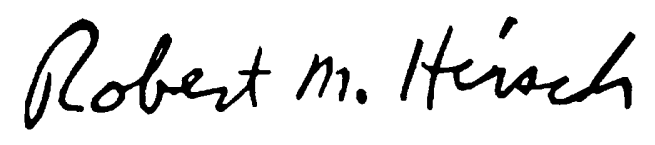

Robert M. Hirsch Chief Hydrologist 



\section{CONTENTS}

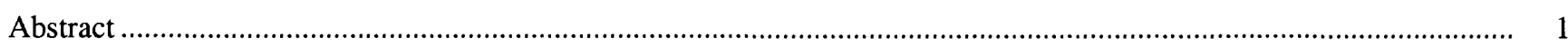

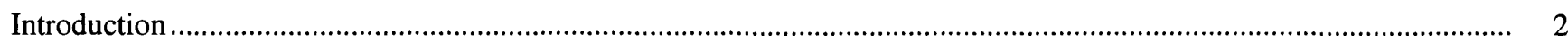

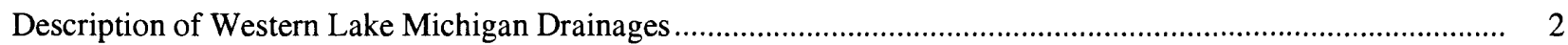

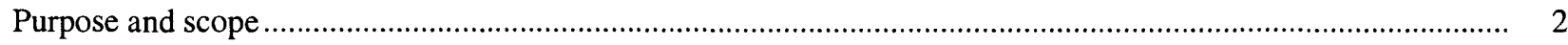

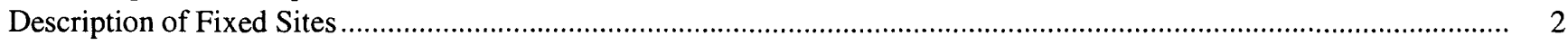

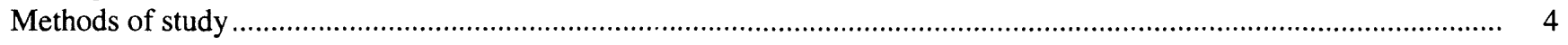

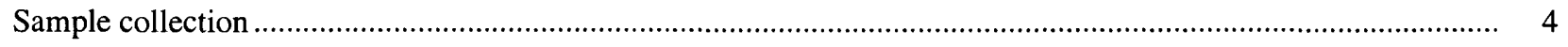

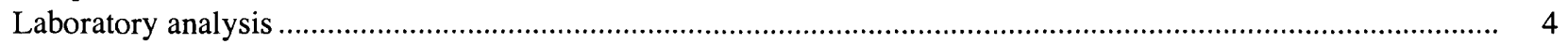

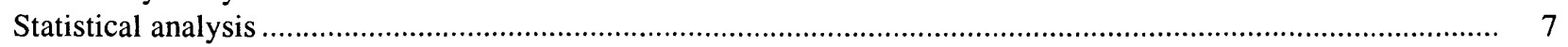

Selected natural and anthropogenic factors in the Study Unit ........................................................................

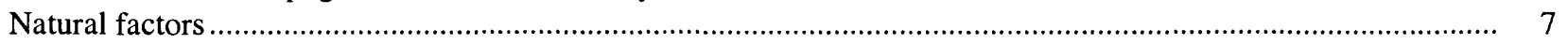

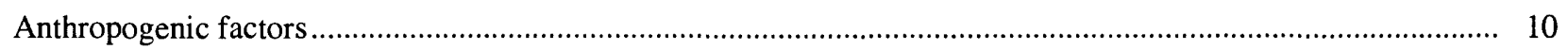

Temporal and spatial variability of surface-water quality at the indicator sites .................................................. 12

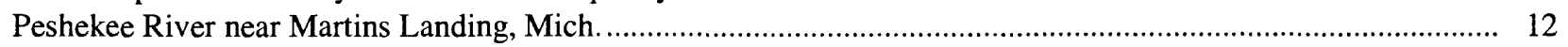

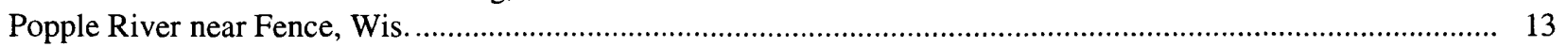

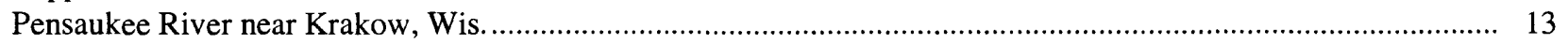

Duck Creek at Seminary Road near Oneida, Wis. ................................................................................. 16

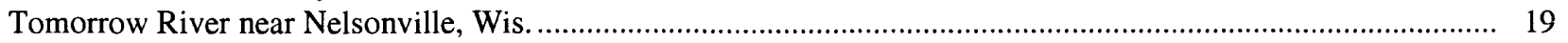

East River at Midway Road near De Pere, Wis. ............................................................................................ 22

North Branch Milwaukee River near Random Lake, Wis. ........................................................................ 22

Lincoln Creek at 47th Street at Milwaukee, Wis. ................................................................................ 23

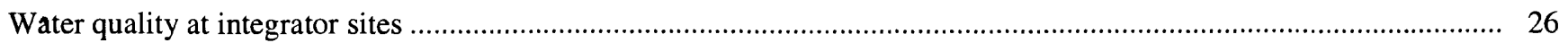

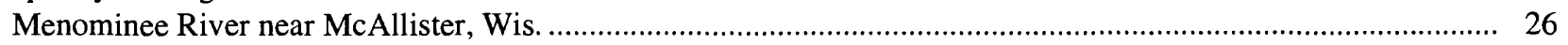

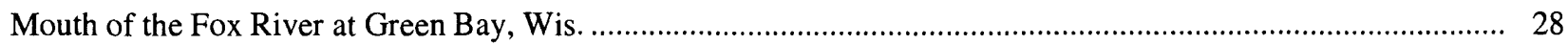

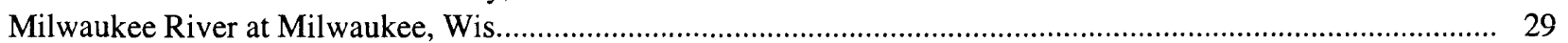

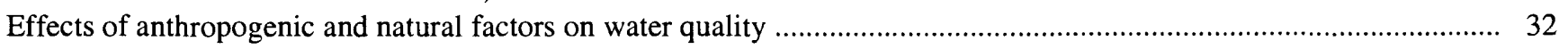

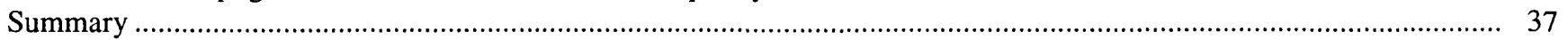

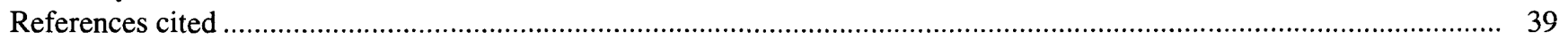

\section{FIGURES}

1-2. Maps showing:

1. Western Lake Michigan Drainages Study Unit of the National Water-Quality Assessment Program.............. 3

2. Boundaries of relatively homogenous units (RHU's) in the Western Lake Michigan Drainages Study Unit and location of Fixed Sites

3. Graphs showing differences in rainfall during the study period from historical average at selected locations in the Western Lake Michigan Drainages Study Unit.......................................................................................

4. Map showing average total annual precipitation in the Western Lake Michigan Drainages Study Unit ................ 10

5-15. Graphs showing relations among rainfall, streamflow and selected properties and constituents of streamflow at the Fixed Sites in Western Lake Michigan Drainages Study Unit

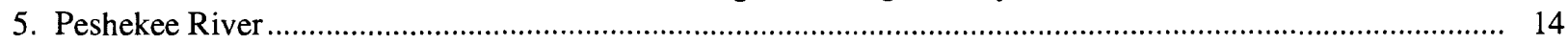

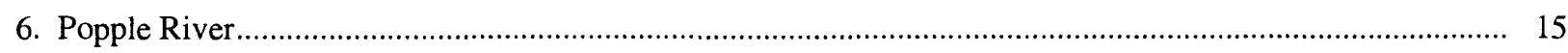

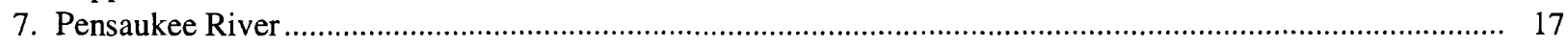

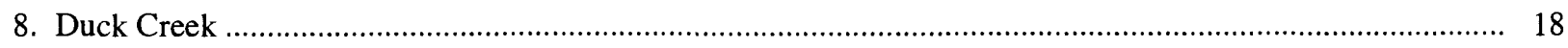

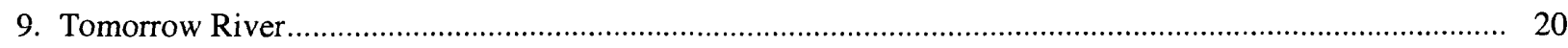

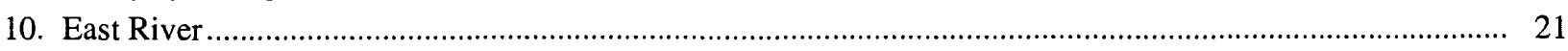

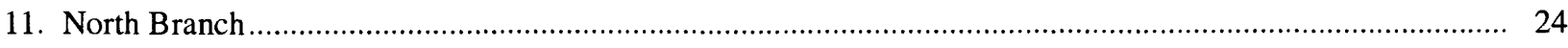

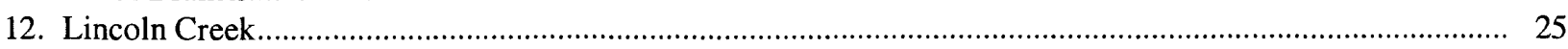

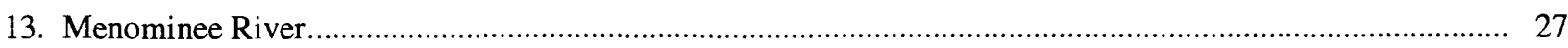

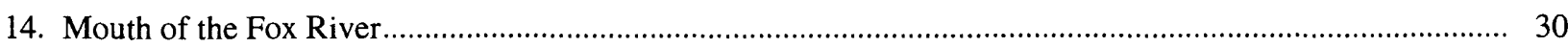

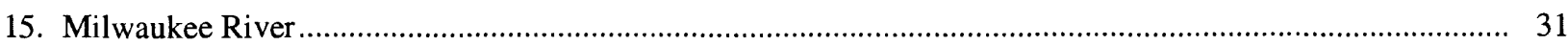




\section{FIGURES-Continued}

16-24. Boxplots showing distribution of concentrations of selected constituents of streamwater at the Fixed Sites in the Western Lake Michigan Drainages Study Unit, 1993-95

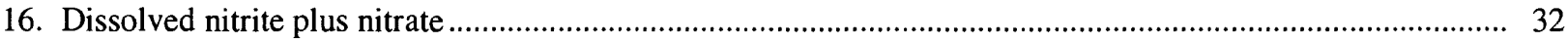

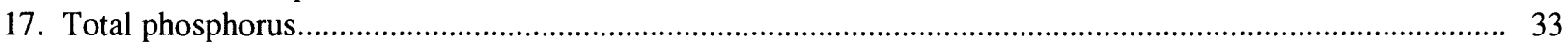

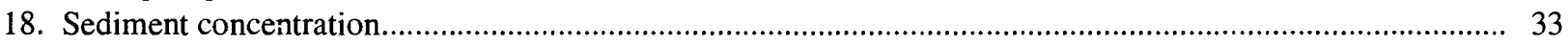

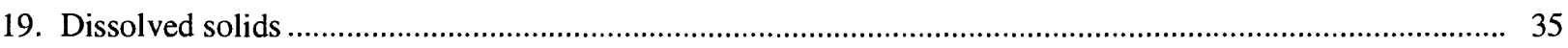

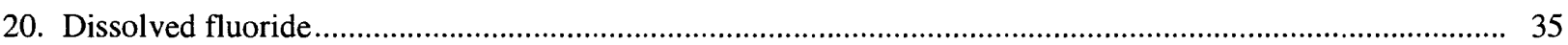

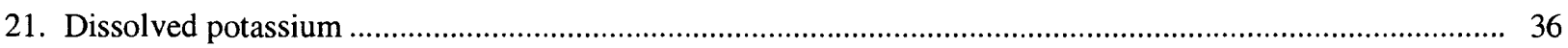

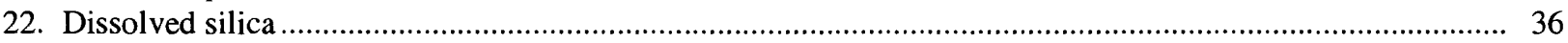

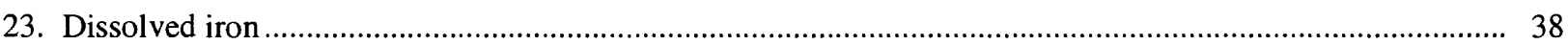

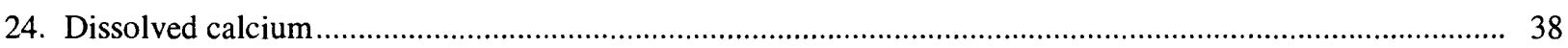

\section{TABLES}

1. Selected information for Fixed Sites and their drainage basins, Western Lake Michigan Drainages Study Unit ..... 6

2. Selected streamwater properties and constituents determined in samples from Fixed Sites in the

Western Lake Michigan Drainages Study Unit

3. Selected information on historic and current cropping patterns at the agricultural indicator sites,

Western Lake Michigan Drainages Study Unit

4. National Median Concentrations (NMC) for selected nutrients by land use/land cover. 


\begin{tabular}{rll}
\hline Multiply & By & To Obtain \\
\hline & & inch \\
centimeter $(\mathrm{cm})$ & 0.3937 & foot \\
meter $(\mathrm{m})$ & 3.281 & mile \\
kilometer $(\mathrm{km})$ & 0.6214 & acre \\
hectare $(\mathrm{ha})$ & 2.471 & acre \\
square kilometer $\left(\mathrm{km}^{2}\right)$ & 247.1 & square mile \\
square kilometer $\left(\mathrm{km}^{2}\right)$ & 0.3861 & quart \\
$\operatorname{liter}(\mathrm{L})$ & 1.057 & gallon \\
$\operatorname{liter}(\mathrm{L})$ & 0.2642 & cubic meter per second $\left(\mathrm{m}^{3} / \mathrm{s}\right)$
\end{tabular}

Temperature, in degrees Celsius $\left({ }^{\circ} \mathrm{C}\right)$ can be converted to degrees Fahrenheit $\left({ }^{\circ} \mathrm{F}\right)$ by use of the following equation: ${ }^{\circ} \mathrm{F}=1.8\left({ }^{\circ} \mathrm{C}\right)+32$.

Abbreviated water-quality units: Chemical concentrations and water temperature are given in metric units. Chemical concentration is given in milligrams per liter $(\mathrm{mg} / \mathrm{L})$ or micrograms per liter $(\mu \mathrm{g} / \mathrm{L})$. Milligrams per liter is a unit expressing the concentration of chemical constituents in solution as weight (milligrams) of solute per unit volume (liter) of water. One thousand micrograms per liter is equivalent to one milligram per liter.

\section{Other Abbreviations used in this Report}

BMP

CRP

HIP

MCL

MDL

NMC

NASQAN

NAWQA

NWQL

PWP

RHU

SU

USEPA

USGS

WDNR

WMIC
Best Management Practices

Conservation Reserve Program

High-Intensity Phase

Maximum Contaminant Level

Method Detection Limit

National Median Concentration

National Stream-Quality Assurance Network

National Water-Quality Assessment Program

U.S. Geological Survey National Water-Quality Laboratory

Priority Watershed Program

Relatively Homogeneous Unit

Study Unit

United States Environmental Protection Agency

United States Geological Survey

Wisconsin Department of Natural Resources

Western Lake Michigan Drainages 


\section{Glossary of Terms}

High-intensity phase

Indicator sites

Integrator sites

Intensive fixed site

Relatively Homogeneous Unit
The sampling period from March 1993 through July 1995.

Sites with drainage basins within one relatively homogeneous unit, samples collected monthly and during selected periods of high flow.

Sites where drainages encompass several relatively homogeneous units, samples collected monthly and during selected periods of high flow.

More frequent sample collection during the growing season, generally 18-22 times per year during 1993 and 1994, and analysis for selected pesticides.

Areas dominated by one specific type of each of three environmental factors thought to be most important in affecting water quality: land use/land zover, surficial deposits, and bedrock.

\section{ACKNOWLEDGMENTS}

\section{Technical Support}

Bernard N. Lenz, Hydrologist, U.S. Geological Survey, Rice Lake, Wis.

Phil A. Kammerer, Hydrologist (Retired), U.S. Geological Survey, Middleton, Wis.

James M. Ellis, Hydrologic Technician, U.S. Geological Survey, Escanaba, Mich.

John C. Knudsen, Hydrologic Technician, U.S. Geological Survey, Escanaba, Mich.

Faith A. Fitzpatrick, Hydrologist, U.S. Geological Survey, Middleton, Wis.

Barbara C. Scudder, Hydrologist, U.S. Geological Survey, Middleton, Wis.

Sharon A. Fitzgerald, Research Hydrologist, U.S. Geological Survey, Middleton, Wis.

Daniel L. Olson, Hydrologic Technician, U.S. Geological Survey, Middleton, Wis.

\section{Technical Reviewers}

Charles A. Peters, Supervisory Hydrologist, U.S. Geological Survey, Middleton, Wis.

Dale M. Robertson, Research Hydrologist, U.S. Geological Survey, Middleton, Wis.

Robert B. Swanson, Hydrologist, U.S. Geological Survey, North Platte, Nebr.

\section{Editorial and Graphics}

C. Michael Eberle, Technical Publications Editor, U.S. Geological Survey, Columbus, Ohio

Betty B. Palcsak, Technical Publications Editor, U.S. Geological Survey, Columbus, Ohio

Gail A. Moede, Student Trainee (Writing/editing), U.S. Geological Survey, Middleton, Wis.

Michelle M. Greenwood, Cartographer, U.S. Geological Survey, Middleton, Wis.

Susan Z. Jones, Editorial Assistant, U.S. Geological Survey, Middleton, Wis.

\section{Approving Officials}

Daniel P. Bauer, Staff Hydrologist, U.S. Geological Survey, Middleton, Wis.

Chester Zenone, Reports Improvement Advisor, U.S. Geological Survey, Reston, Va. 


\title{
Surface-Water Quality at Fixed Sites in the Western Lake Michigan Drainages, Wisconsin and Michigan, and the Effects of Natural and Human Factors, 1993-95
}

\author{
By Kevin D. Richards, Daniel J. Sullivan, and Jana S. Stewart
}

\section{Abstract}

Streamwater samples were collected from April 1993 through July 1995 at 11 Fixed Sites in the Western Lake Michigan Drainages Study Unit of the U.S. Geological Survey's National Water-Quality Assessment Program. Water samples were collected monthly at all Fixed Sites, and an additional two to four samples were collected each year at each site during periods of high flow. Streamflow was monitored continuously at the Fixed Sites for the duration of the study period. This report describes field techniques used to collect the water samples, and the analytical methods used for laboratory analyses, statistical analyses of the data, and an attempt to determine the effect of natural and anthropogenic factors on concentrations of nutrients and selected major ions and suspended solids.

Locations of eight of the Fixed Sites were selected to represent areas with unique combinations of land use/land cover, surficial deposits, and bedrock geology and are referred to as "indicator sites." The remaining three sites were located near the mouths of major rivers and are referred to as "integrator sites." The integrator sites represent a large part of the total flow from the Study Unit to Green Bay and western Lake Michigan, and drain various combinations of land use, bedrock, and surficial deposits.

These data indicate that land use and surficial deposits may be the primary factors affecting nitrate and total-phosphorus concentrations in this Study Unit. Median concentrations of nitrate at the forested sites were less than the National Median Concentration (NMC), and those at urban Fixed Sites were similar to the NMC.
Median nitrate concentrations at the Tomorrow River, North Branch Milwaukee River, and Duck Creek agricultural indicator sites were twice the $\mathrm{NMC}$, but median concentrations at the remaining agricultural indicator sites were similar to the NMC. Nitrate concentrations at one agricultural indicator site exceeded the U.S. Environmental Protection Agency (USEPA) maximum contaminant level in three runoff samples in the growing seasons of 1994 and 1995.

Median concentrations of total phosphorus at the forested indicator sites were below the NMC. Tomorrow River was the only agricultural indicator site where the median total-phosphorus concentration was less than the NMC; median concentrations at the remaining agricultural Fixed Sites were similar to the NMC and exceeded 0.10 $\mathrm{mg} / \mathrm{L}$, the USEPA suggested total-phosphorus concentration in flowing water. The USEPA recommends that total-phosphorus concentration not exceed this limit to discourage excessive aquatic growth in flowing waters. Median total-phosphorus concentration at the urban indicator site was less than the urban NMC.

Median concentrations for both nitrate and total phosphorus at the mouth of the Fox River and the Milwaukee River integrator sites were similar to the NMC for the dominant land use-agriculture-within their basins, and were higher than median concentrations at the Menominee River integrator site with a dominant forest land use.

During this study, potassium concentrations were generally highest in areas of clay-dominated surficial deposits, silica was generally highest in areas of sandy surficial deposits, iron generally highest in areas of igneous/metamorphic bedrock, and calcium generally highest in areas of carbon- 
ate bedrock. The highest median fluoride concentration occurred at an urban site that receives treated water.

\section{INTRODUCTION}

In 1991, the U.S. Geological Survey (USGS) began implementation of the National Water-Quality Assessment (NAWQA) Program (Hirsch and others, 1988). Various NAWQA Study Units were planned to begin data-collection activities on a staggered time scale. The Western Lake Michigan Drainages (WMIC) Study Unit was one of the first 20 Study Units to begin data collection and analysis in 1991. The NAWQA Program uses a multidisciplinary approach, which includes biological, physical, and chemical assessments of water quality at selected Fixed Sites on streams where water stage is monitored continuously and the relation between water stage and discharge (flow) is determined.

In the Western Lake Michigan Drainages, 11 Fixed Sites were established and sampled during the highintensity phase of the study which lasted from April 1993 through July 1995. Water samples were collected once a month at the Fixed Sites and additional samples were collected during runoff periods. Water samples collected during this period were analyzed for nutrients, major ions, organic carbon, and suspended sediments.

\section{Description of the Western Lake Michigan Drainages}

The Western Lake Michigan Drainages NAWQA Study Unit encompasses $51,540 \mathrm{~km}^{2}$ in eastern Wisconsin and part of the Upper Peninsula of Michigan (fig. 1). The Study Unit, which includes 10 major river systems draining to Lake Michigan, is bounded on the south by the Illinois state line and extends north to about $50 \mathrm{~km}$ north of Escanaba, Mich. The following major rivers drain directly to Green Bay: the Escanaba and Ford Rivers in the Upper Peninsula of Michigan; the Menominee River, which forms much of the border between Michigan and Wisconsin; the Oconto, Peshtigo, and the Fox/ Wolf River in Wisconsin (the largest system in the Study Unit). The Manitowoc, Sheboygan, and Milwaukee Rivers in Wisconsin all drain directly to the western side of Lake Michigan.

The overall population of the Study Unit is about $2,435,000$ (U.S. Bureau of the Census, 1991), with urban land found mostly in the southern half of the Study Unit, but accounting for less than 4 percent of the
Study Unit. The Milwaukee River Basin in the southeastern part of the Study Unit has the largest population. Major cities and their populations are:

Milwaukee: 628,000; Green Bay, 96,000; Racine, 84,000; Kenosha, 80,000; and Appleton, 66,000. Forests cover about 40 percent of the Study Unit, mostly in the northern part. Agriculture, mainly cropland and pastureland used for the dairy industry, accounts for 37 percent of the land use. Cropland predominates in the southern part of the Study Unit. Wetlands account for about 15 percent of the land cover. Lake Winnebago, a 55,440-hectare lake in the Fox/Wolf River Basin, is a major surface-water feature.

Surficial deposits consist primarily of unconsolidated glacial, fluvial, and eolian materials. The texture of these deposits is classified as predominantly sand or sand and gravel in the north and west and as clay in the southeast. Loam covers some north and central areas (Robertson and Saad, 1995). The bedrock underlying the Study Unit consists of igneous and metamorphic rocks in the northwest, sandstone in the southwest, and carbonate rocks in the northeast (Robertson and Saad, 1996).

The Western Lake Michigan Drainages NAWQA Study Unit was divided into 28 areas with unique combinations of bedrock geology, surficial deposits, and land use/land cover for selection of Fixed Site locations. These areas are referred to as "relatively homogeneous units" (RHU's). A complete description of RHU's is given by Robertson and Saad (1995).

\section{Purpose and Scope}

This report summarizes (1) streamwater chemical data collected at the 11 Fixed Sites in the Western Lake Michigan Drainages during the high-intensity phase of the study (April 1993 through July 1995), (2) environmental conditions during the study period, and (3) land use/land cover and agricultural practices, the key anthropogenic factors in the Study Unit, and (4) compares and contrasts water quality at the 11 Fixed Sites during the sampling period in relation to environmental conditions and land use/land cover.

\section{DESCRIPTION OF FIXED SITES}

The Fixed-Site network for the Western Lake Michigan Drainages NAWQA consists of 11 sites (fig. 2). The Fixed Sites are described briefly here; a 


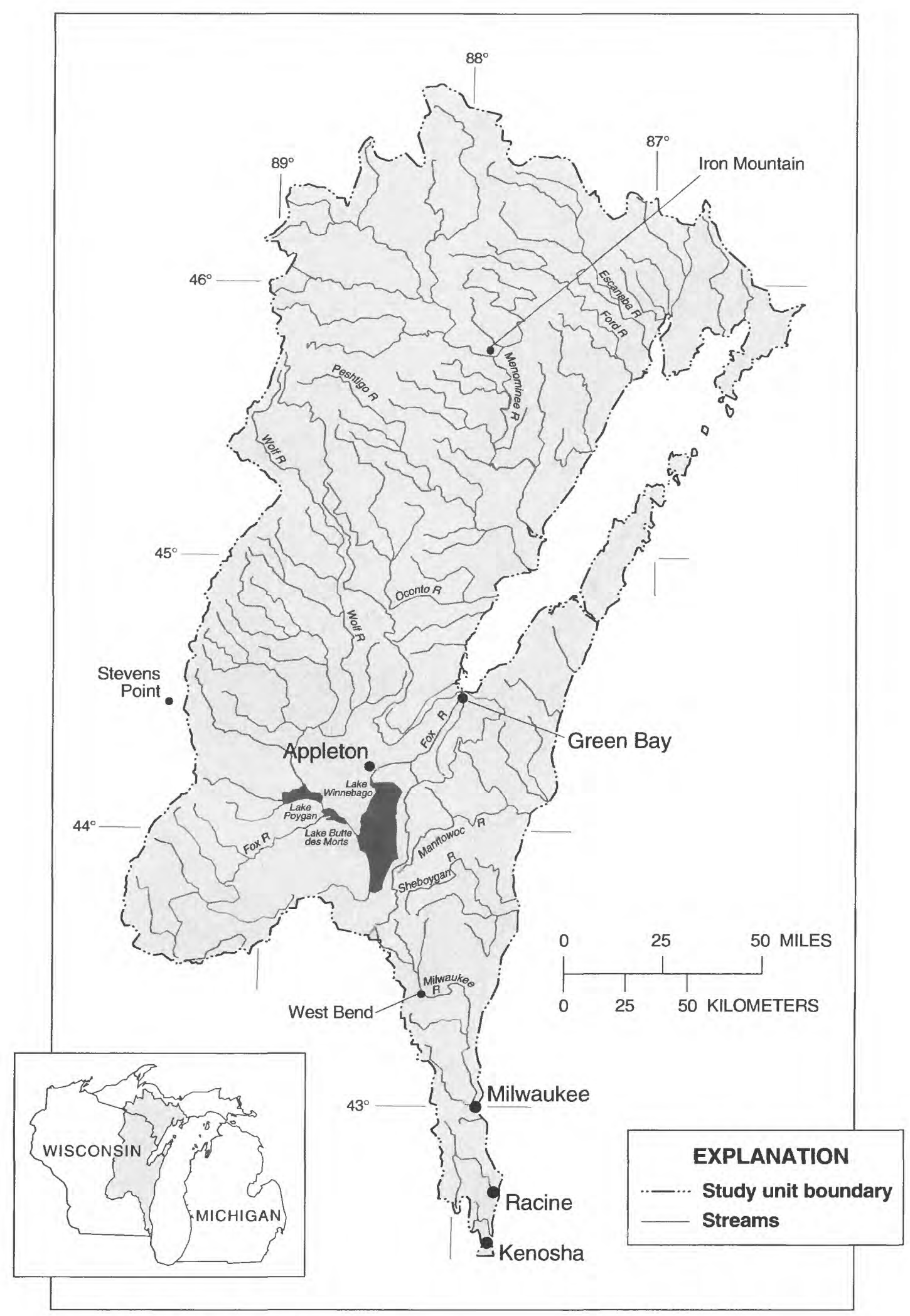

Source: Seaber and others, 1986.

Figure 1. Western Lake Michigan Drainages Study Unit of the National Water-Quality Assessment Program. 
more complete site-by-site description is in Sullivan and others (1995).

Of the 11 Fixed Sites, 8 have drainage basins entirely within one RHU. These sites are referred to as "indicator" sites because water quality at these sites is assumed to be indicative of conditions within that RHU. Four sites were chosen to represent agricultural areas, 2 sites to represent forested areas, 1 site to represent mixed agriculture/forest areas, and 1 site to represent an urban area.The indicator sites have relatively small drainage areas (less than $400 \mathrm{~km}^{2}$ ). The other three Fixed Sites were chosen near the mouths of major rivers to represent a large part of the total flow from the Study Unit to Green Bay and western Lake Michigan (Sullivan and others, 1995). These sites are referred to as "integrator" sites because the drainages of each encompass - and thus integrate the effects of - several RHU's. Selected information on the Fixed Sites is listed in table 1. Sullivan and others (1995) describe the environmental setting of the Fixed Sites in greater detail.

\section{METHODS OF STUDY}

This section describes field sample collection methods, laboratory analytical methods, and statistical techniques used to analyze data for this report. In addition, these discussions contain references to more detailed information about these methods.

\section{Sample Collection}

The 11 Fixed Sites were sampled monthly during the high-intensity phase of the study. Additional samples were collected at each site during runoff events (April 1993 through July 1995). All water samples were collected using standard NAWQA protocols (Shelton, 1994).

Samples were analyzed for concentrations of suspended sediment, nutrients, major ions, and organic carbon. Water temperature, $\mathrm{pH}$, specific conductance, dissolved oxygen, and alkalinity were measured in the field. The field measurement data are summarized in Sullivan and others (1995).

Three sites, two indicator, and one integrator, were selected for intensive sampling, which entailed more frequent sample collection during 1993 and 1994 as well as the collection of samples for pesticide analysis. These sites are referred to as "intensive" indicator or integrator Fixed Sites. During the 1994 growing season pesticide samples were also collected at an additional three indicator sites.

The specific sampling equipment used depended on stream conditions. At wadable sites, samples were collected by use of a USGS DH-81 sampler. At nonwadable sites, a USGS D-77TM (trace metal) sampler was used. Samples were collected at equal-width increments. Approximately 15 cross-section verticals were sampled and composited.

Conditions at the Fox River site required use of a nonstandard sampler. A 1-liter Teflon ${ }^{1}$ Kemmerer type sampler was used because the river is deep $(\sim 9 \mathrm{~m})$, and flow reversals can occur. In general, the velocity at this site was less than $0.3 \mathrm{~m}^{3} / \mathrm{s}$.

Nonstandard samplers were also used when streams were ice covered. Sampling methods used during ice periods were weighted bottle samplers and (or) dip samples. Methods and equipment used to composite samples prior to October 1993, were either a 20-liter aluminum cream can or a plastic churn splitter, depending on the analysis requirements. Beginning in October 1993, samples were collected in 3-liter Teflon or plastic containers and split into sample containers through a Teflon Deka-port splitter (U.S. Geological Survey, WRD Memo, 1993).

The technique used for preservation of water samples collected for nutrient analysis changed on October 1, 1993. Prior to this, nutrient samples were preserved with $0.5 \mathrm{~mL}$ of mercuric chloride $(\mathrm{HgCl})$ and shipped to the USGS National Water-Quality Laboratory (NWQL), chilled. Beginning on October 1, 1993, nutrient sample preservation no longer included adding $\mathrm{HgCl}$ (U.S. Geological Survey, NWQL Memo, 1994).

\section{Laboratory Analysis}

All samples collected during the study period were analyzed at the NWQL using methods described in detail in Fishman and Friedman (1989). Parameter codes and laboratory Method Detection Limits (MDL) at the NWQL for samples analyzed for nutrients and selected common constituents and major ions at the Fixed Sites is listed in table 2. One change in MDL occurred for dissolved ammonia (as N). Beginning in October 1994, the MDL changed from

\footnotetext{
${ }^{1}$ Use of brand or trade names is for identification purposes only and does not constitute endorsement by the U.S. Geological Survey.
} 


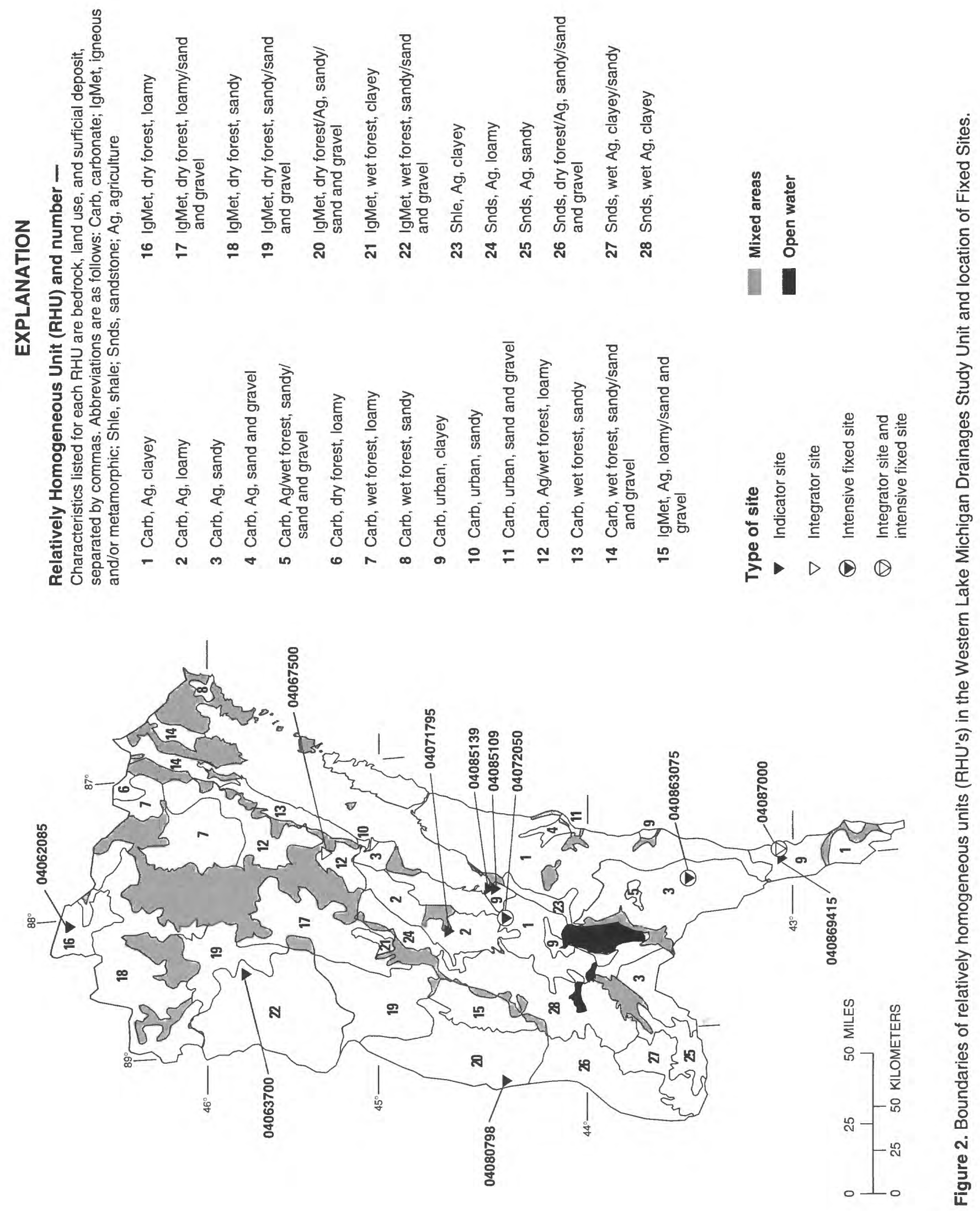




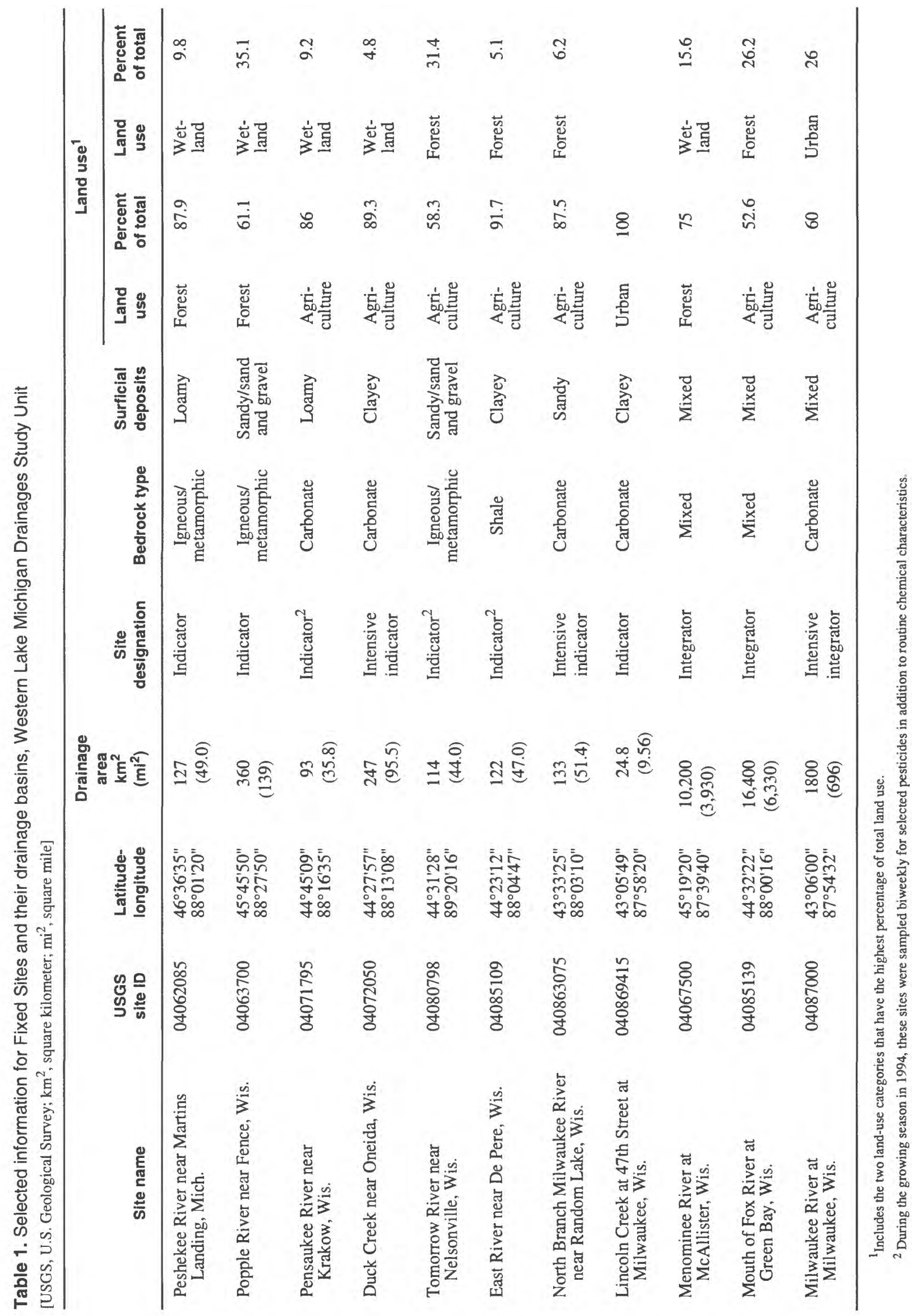


0.010 milligrams per liter $(\mathrm{mg} / \mathrm{L})$ to $0.015 \mathrm{mg} / \mathrm{L}$. Results and interpretation of QA/QC data collected as part of this study is described in detail in Fitzgerald (1997).

\section{Statistical Analysis}

Spearman's rank coefficients were calculated to determine correlations between the 8 nutrients and 10 major ions and dissolved solids, and to determine how well specific constituents could be used to represent the suite of nutrients and major ions (Inman and Conover, 1983). From the groups of constituents that were highly correlated, a representative constituent was selected and used to illustrate patterns in changes of concentrations at a Fixed Site. Total phosphorus correlated (rho $=0.60$ 0.88 ) with all nutrients except dissolved nitrite plus nitrate (for the purposes of this report dissolved nitrite plus nitrate will be referred to as "nitrate"). Total phosphorus was also correlated (rho $=0.5-0.77$ ) with calcium, magnesium, sodium, potassium, chloride, and sulfate. Fluoride, silica, iron, and manganese concentrations did not correlate well with concentrations of any major ions or nutrients. For this report total phosphorus was used to graphically represent the constituents with which it was highly correlated.

A discriminator characteristic was selected for each site. In most cases the constituent selected shows how the particular site is different from the other Fixed Sites.

Significant differences in concentrations of total phosphorus, nitrate, and the discriminator characteristic were tested for by using Tukey Studentized $t$-tests between all Fixed Sites $(\alpha=0.05)$ (SAS Institute Inc., 1990; Inman and Conover, 1983). For the purpose of all calculations, values for total phosphorus, nitrate, and major ions reported as less than the MDL, were set at one half of the MDL.

\section{SELECTED NATURAL AND ANTHROPOGENIC FACTORS IN THE STUDY UNIT}

This section details selected information on surficial deposits, bedrock, climatic, and land use differences, and other factors that may affect the surfacewater quality at the Fixed Sites.

\section{Natural Factors}

The surficial deposits in the WMIC Study Unit are divided into five types based on texture: sand and gravel, sand, loam, clay, and peat, and range in thickness from zero to several hundred feet. The surficial deposits consist of glacial and recent-aged deposits. Sandy and sand and gravel surficial deposits are found predominately in the west, south, and northwestern part of the Study Unit. Sandy deposits in the southern part of the Study Unit are associated with till. Clayey and loamy deposits are found in the central, eastern, and northeastern part of the Study Unit. In the low-lying, poorly drained areas in the northern part of the Study Unit, peat is the predominant surficial deposit.

Bedrock in the Study Unit dips towards Lake Michigan with the oldest rock subcrops in the northwest and the youngest in the southeast. There are four types of bedrock in the Study Unit: igneous/metamorphic, sandstone, carbonate, and shale. Additional information on bedrock and surficial deposits in the Study Unit is presented in Robertson and Saad (1995).

The climate of the study area is temperate, characterized by a large range in annual temperature. Distribution of annual rainfall is shown in figure 3 . Annual precipitation ranges from $71 \mathrm{~cm}$ in the central part of the Study Unit to $81 \mathrm{~cm}$ near Lake Superior and in the southern areas of the Study Unit. Historical rainfall data were obtained from the Midwest Climate Center, and data for the high-intensity period were obtained from the Wisconsin and Michigan State Climatologists. Additional climatic data are presented in Robertson and Saad (1996).

Precipitation varies seasonally, with 60 percent occurring between May and September (Robertson and Saad, 1996). The 1993 growing season (April through September) was the wettest during the 3-year, highintensity phase (fig. 4). Extensive flooding occurred in the Study Unit in the spring and early summer of 1993 , as it did in much of the Midwest. Many farmers modified their planting regime, planting later in the season and using fewer amendments (fertilizers and pesticides) to deal with the atypical conditions (interviews with farmers in the Duck Creek and the North Branch Milwaukee River Basins). Monthly rainfall in the West Bend area, which includes the North Branch Milwaukee, the Lincoln, and the Milwaukee Rivers, were above monthly normal totals (normal rainfall totals are based on average precipitation from 1961-90). Above normal rainfall for the same time period was recorded in 
Table 2. Selected streamwater properties and constituents determined in samples from Fixed Sites in the Western Lake Michigan Drainages Study Unit

[NWQL, U.S. Geological Survey National Water-Quality Laboratory; ${ }^{\circ} \mathrm{C}$, degrees Celsius; $\mathrm{mg} / \mathrm{L}$, milligrams per liter; $\mu \mathrm{g} / \mathrm{L}$, micrograms per liter. For common constituents and nutrients, the sample was passed through a 0.45-micrometer filter; MDL in milligrams per liter unless otherwise noted; constituents are dissolved unless otherwise noted; $N$, nitrogen; $P$, phosphorus]

\begin{tabular}{|c|c|c|}
\hline Constituent & $\begin{array}{l}\text { NWQL } \\
\text { parameter } \\
\text { code }\end{array}$ & $\begin{array}{l}\text { Laboratory } \\
\text { Method Detection } \\
\text { Limit (MDL) }\end{array}$ \\
\hline \multicolumn{3}{|c|}{ Nutrients } \\
\hline Ammonia, as $\mathrm{N}$ & 00608 & ${ }^{1} 0.015$ \\
\hline Ammonia plus organic nitrogen, as $\mathrm{N}$ & 00623 & .2 \\
\hline Ammonia plus organic nitrogen, as $\mathrm{N}$, total & 00625 & .2 \\
\hline Nitrite, as $\mathrm{N}$ & 00613 & .01 \\
\hline Nitrite plus nitrate, as $\mathrm{N}$ & 00631 & .05 \\
\hline Orthophosphate, as $\mathrm{P}$ & 00671 & .01 \\
\hline Phosphorus, as P, total & 00665 & .01 \\
\hline Phosphorus, as $\mathrm{P}$ & 00666 & .01 \\
\hline \multicolumn{3}{|c|}{ Major ions } \\
\hline Calcium & 00915 & .02 \\
\hline Chloride & 00940 & .1 \\
\hline Fluoride & 00950 & .1 \\
\hline Iron & 01046 & $3.0 \mu \mathrm{g} / \mathrm{L}$ \\
\hline Magnesium & 00925 & .01 \\
\hline Manganese & 01056 & $1.0 \mu \mathrm{g} / \mathrm{L}$ \\
\hline Potassium & 00935 & .1 \\
\hline Silica & 00955 & .01 \\
\hline Sodium & 00930 & .2 \\
\hline Sulfate & 00945 & .1 \\
\hline \multicolumn{3}{|c|}{ Common constituent } \\
\hline Dissolved solids (residues at $180^{\circ} \mathrm{C}$ ) & 70300 & 1 \\
\hline
\end{tabular}

${ }^{1}$ Method Detection Limit change on Oct. 1, 1994, from $0.010 \mathrm{mg} / \mathrm{L}$ to $0.015 \mathrm{mg} / \mathrm{L}$. 

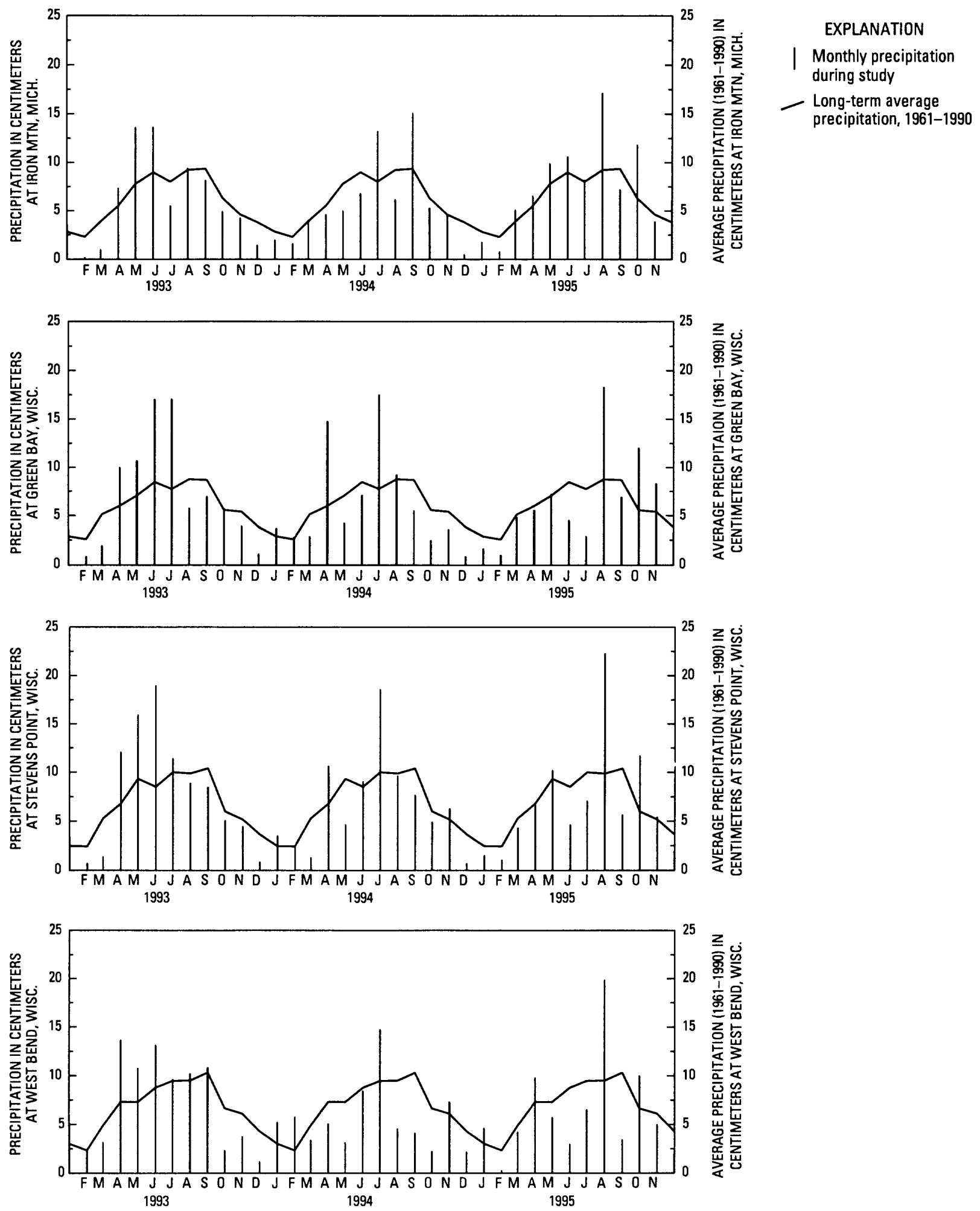

Figure 3. Difference in rainfall during study period from historical average at selected locations in the Western Lake Michigan Drainages Study Unit. 


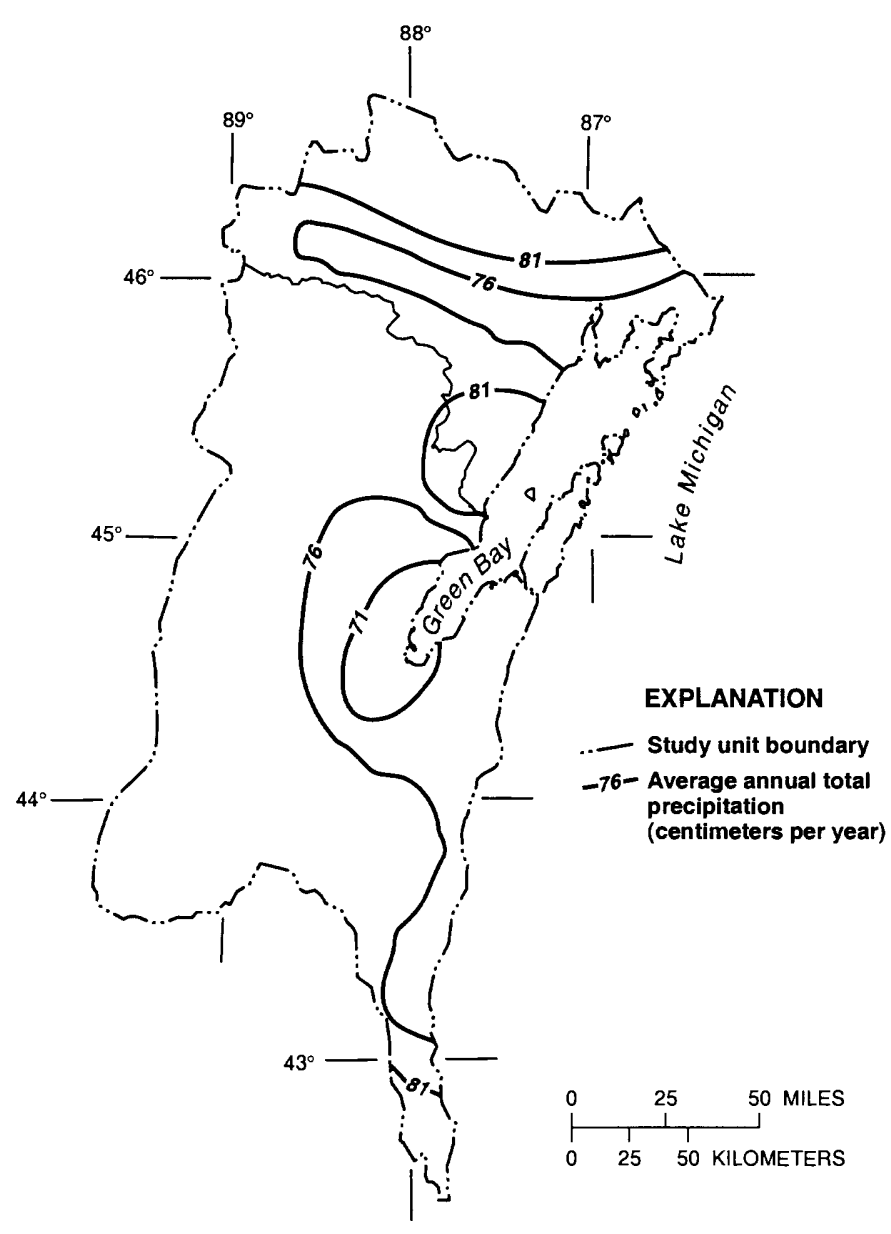

Figure 4. Average total annual precipitation (in centimeters) in the Western Lake Michigan Drainages Study Unit (from Wendland and others, 1985).

the Green Bay, Wis. area (Menominee, Pensaukee, Duck, East, and Fox Basins), the Stevens Point, Wis. area (Tomorrow River), and the Iron Mountain, Mich. area (Peshekee and Popple Rivers). Precipitation in 1994 and 1995 was near normal prior to planting and below normal in late spring (April-June), allowing farmers to plant their crops and apply amendments earlier than in 1993. Heavy rains in July and August 1994 occurred at a time when heavy ground cover was present, which dissipated the raindrop energy, which combined with uptake from the plants, reduced surface runoff. The highest daily mean discharges were observed in the 1993 growing season.

\section{Anthropogenic Factors}

Five of the Fixed Sites, North Branch Milwaukee River, East River, Pensaukee River, Duck Creek, and
Lincoln Creek were in Wisconsin Department of Natural Resources (WDNR) priority watersheds (Wisconsin Department of Natural Resources, 1995). Areas selected to be in the Priority Watershed Program (PWP) receive state funding to help pay the cost of controlling pollution from runoff through implementation of best management practices (BMP's). Because of limited funding, the watersheds chosen for the PWP are those where problems are critical.

The percentage of agricultural land in the agricultural Fixed-site basins has not changed significantly since the mid-1970's. Changes have occurred, however, in the acreage of specific crops grown (Anderson and others, 1976; Stewart, 1994; Stewart, 1995) (table 3). The percentage of agricultural land devoted to growing oats has decreased since the mid-1960's. During the same period there has been an increase in land devoted to field corn for all agricultural basins; sweet corn for the North Branch Milwaukee River, and soybeans for Duck Creek, the East River, and the North Branch Milwaukee River Basins. The percentage of agricultural land devoted to forage crops since 1964 has remained relatively stable for all agricultural Fixed-site basins, with the exception of the Tomorrow River Basin, where acreage in forage crops appears to be decreasing and that in cash crops such as peas, sweet corn, and snapbeans seems to be increasing. This trend in the Tomorrow River Basin may be an artifact of the source data used to make the crop acreage calculations. Portions of Portage County that are not in the Tomorrow River Basin are irrigated and are being converted to those cash crops.

During the years of high intensity water-quality sampling, there was little variation in the acreage of land under contract by the Conservation Reserve Program (CRP) (Wisconsin Department of Agriculture, Trade and Consumer Protection, 1966, 1975, 1985, 1994-96) with the exception of the Duck Creek Basin where land in CRP increased 30 percent between 1993 and 1995. Agricultural land in CRP is generally planted in grass and left uncropped for as long as 10 years. The CRP was implemented in 1986 to help owners and operators with highly erodible cropland, which poses a threat to degradation of water quality, to conserve and improve the soil and water resources 


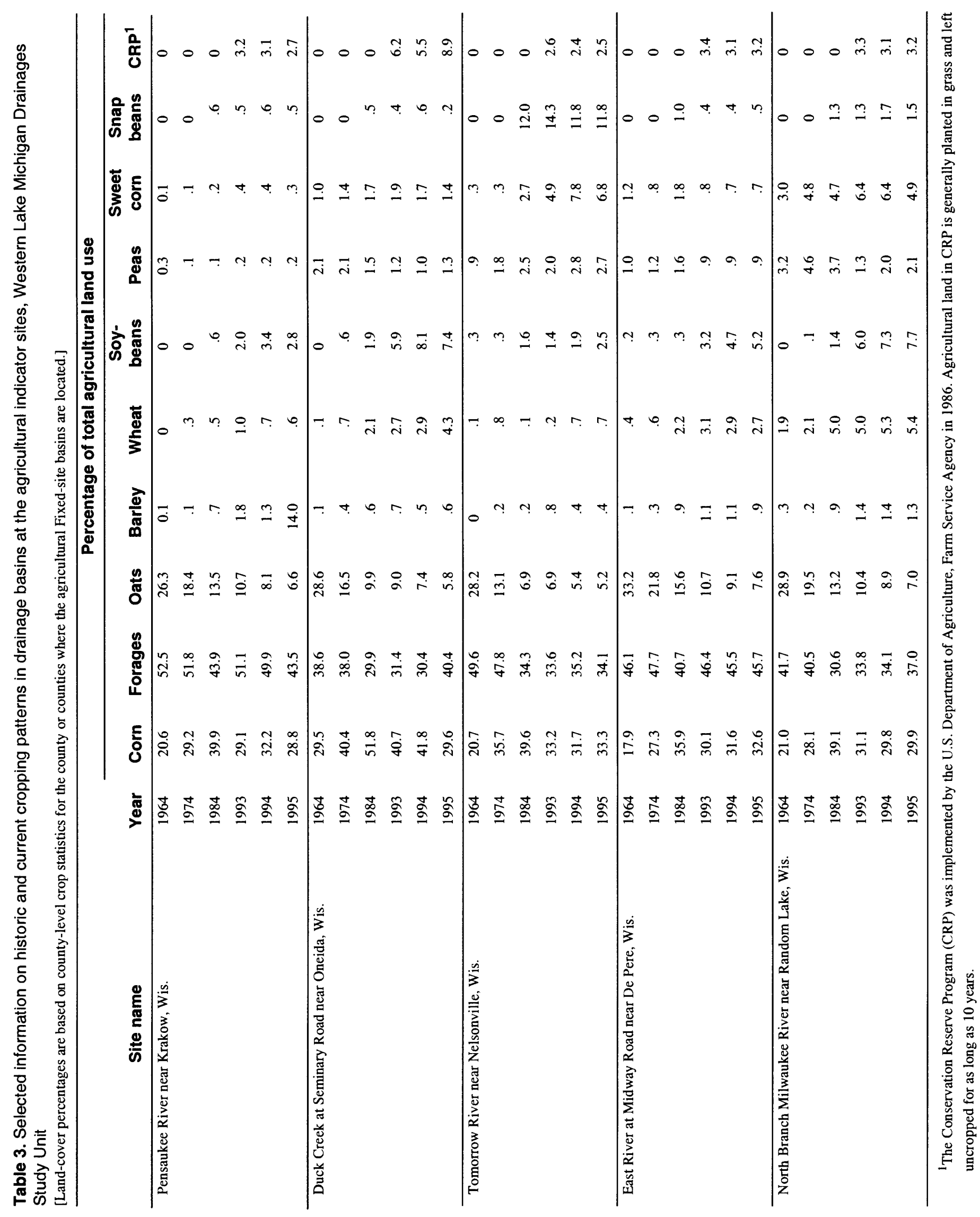


of their farms (U.S. Department of Agriculture, Farm Service Agency, 1997). The basin with the greatest percentage of land in CRP is Duck Creek; the other agricultural Fixed-site basins have only half as much land in the program.

The most obvious change in land use near a Fixed Site during the high-intensity phase was an extensive clear-cut in the Peshekee River Basin in the summer of 1994. A 20-m riparian buffer of trees was left between the clear-cut area and the Peshekee River, but most of the basin was completely clear-cut of trees.

Manure is the primary nutrient source in areas with dairy operations. Commercial fertilizers were the primary nutrient source in areas of cash cropping and in urban areas. Additional historical data for analysis of nutrient data and historical fertilizer inputs is given in Robertson and Saad (1996).

\section{TEMPORAL AND SPATIAL VARIABILITY OF SURFACE-WATER QUALITY AT THE INDICATOR SITES}

Selected water-quality characteristics and general characteristics of the indicator Fixed Sites during 199395 are described in this section. Concentrations of selected constituents are also compared to concentrations at sites with similar land use/land cover in other areas of the United States.

\section{Peshekee River near Martins Landing, Mich.}

The Peshekee River near Martins Landing, Mich., drains $127 \mathrm{~km}^{2}$ of forested land in the extreme northwestern part of the Study Unit prior to emptying into the Menominee River. Thin surficial deposits, bedrock outcrops, wetlands, and a short growing season limit this basin's land use to forests. Wetlands in the headwaters of the basin and ground-water discharge maintain base flow. Tannins from decaying vegetation give the water a tea-like appearance. The watershed of the Peshekee River at Martins Landing has no agricultural activity (except for silviculture). The Peshekee River Basin is in a relatively pristine area where wolf and moose roam remote forests. During the summer of 1994, the forests in the watershed were clear-cut for pulpwood, with only a 20 to 30 -meter-wide buffer of uncut trees and vegetation left along the river's edge. The highest daily mean streamflows during the study period occurred during periods of snowmelt and spring breakup during March through May. Most of the high-flow samples from the Peshekee River Fixed Site were collected during these periods. The lowest daily mean flows occurred during July-September 1993 and August-September 1995 (fig. 5). Thirty-one water samples were collected at the Peshekee River site during the study period.

Nitrate concentrations ranged from below the MDL of 0.05 to a maximum of $0.20 \mathrm{mg} / \mathrm{L}$. The median concentration of nitrate $(0.073 \mathrm{mg} / \mathrm{L})$ was lower than the National Median Concentration (NMC) for forested areas (Smith and others, 1993).The NMC's for nitrate and total phosphorus for various land uses (Smith and others, 1993) are listed in table 4.

The data indicate a seasonality in nitrate concentrations; generally, higher concentrations were found in samples collected during the November-to-April period in each of the study years. Samples collected during storms in late spring through late summer had concentrations at or just above the MDL. Increased groundwater recharge relative to runoff and reduced consumption by dormant aquatic organisms might account for the higher nitrate concentrations in the winter.

Total-phosphorus concentrations ranged from below the MDL of $0.01 \mathrm{mg} / \mathrm{L}$ to a maximum of 0.05 $\mathrm{mg} / \mathrm{L}$. The median concentration for phosphorus was at the MDL and was lower than the $0.05 \mathrm{mg} / \mathrm{L} \mathrm{NMC}$ for forested areas (Smith and others, 1993). Only one sample collected during the study period had a total-phosphorus concentration near the NMC.

Suspended-sediment concentrations ranged from $1.0 \mathrm{mg} / \mathrm{L}$ to a maximum of $78 \mathrm{mg} / \mathrm{L}$. The median concentration was $2.0 \mathrm{mg} / \mathrm{L}$. The highest concentration was found in a sample collected in April 1993. Not enough data are available to determine if the clear-cutting in 1994 affected suspended-sediment concentrations at this site.

The median concentration of dissolved solids at the Peshekee River site was significantly lower than at any other Fixed Site; thus, dissolved solids was used as the discriminant constituent at this site. Dissolved-solids concentrations ranged from 27 to $69 \mathrm{mg} / \mathrm{L}$; the median concentration was $47 \mathrm{mg} / \mathrm{L}$. The highest sampled concentrations generally were found during late summer. The median concentration of dissolved solids was lower by at least an order of magnitude than at all other Fixed Sites. 
Table 4. National Median Concentrations (NMC) for selected nutrients by land use/land cover

[All concentrations in milligrams per liter; $\mathrm{N}$, nitrogen]

\begin{tabular}{lcc}
\hline Land use/land cover & Nitrite plus nitrate (as N) & Total phosphorus \\
\hline Agricultural & 0.72 & 0.23 \\
Forested & .21 & .05 \\
Urban & .47 & .20 \\
\hline
\end{tabular}

\section{Popple River near Fence, Wis.}

The Popple River near Fence, Wis., drains $360 \mathrm{~km}^{2}$ of mostly forested land in the northwestern part of the Study Unit, in the Menominee River Basin. Much of the drainage is in the Nicolet National Forest. The sampling site is a benchmark site in the USGS National StreamQuality Accounting Network (NASQAN). The

NASQAN benchmark sites are a network of sites across the country in small, undeveloped drainage basins in which land use is not expected to change significantly in the foreseeable future (Hooper and others, 1997). Extensive wetlands within the Popple River Basin help buffer extremes in streamflow and serve as a water source for the river. The combination of heavy forest canopy and highly permeable surficial deposits allows for fast infiltration of precipitation and low surface runoff. Tannins from vegetation stain the water in the basin and give it a tea-like appearance. Above-normal precipitation in the spring and early summer 1993 (AprilJune) resulted in the highest daily mean streamflow during the study period. Over one-half of the storm samples were collected at the Popple River site during this time period (fig. 6). Forty water samples were collected at the Popple River Fixed Site during the study period.

Nitrate concentrations ranged from below the 0.05 $\mathrm{mg} / \mathrm{L} \mathrm{MDL}$ to $0.2 \mathrm{mg} / \mathrm{L}$. The median concentration of nitrate $(0.057 \mathrm{mg} / \mathrm{L})$ was lower than the NMC. The highest nitrate concentrations were found between November and May during periods of lowest daily mean streamflow. These concentrations indicate a seasonality to nitrate concentration at this site during the study period.

Total-phosphorus concentrations ranged from below the $0.01 \mathrm{mg} / \mathrm{L}$ MDL to a maximum of 0.04 $\mathrm{mg} / \mathrm{L}$; the median concentration was $0.02 \mathrm{mg} / \mathrm{L}$. The median concentration of phosphorus at the Popple River site was lower than the $0.05 \mathrm{mg} / \mathrm{L}$ NMC (Smith and others, 1993). Total-phosphorus concentrations were gen- erally highest during the growing season, May to September, and during increased streamflow.

Suspended-sediment concentrations ranged from $2 \mathrm{mg} / \mathrm{L}$ to a maximum of $19 \mathrm{mg} / \mathrm{L}$; the median concentration was $4.0 \mathrm{mg} / \mathrm{L}$. The highest sampled concentration came from a high-flow sample in June 1993.

The highest iron concentrations of the Fixed Sites were found at the Popple and Peshekee River sites; thus, iron was selected as the discriminator characteristic for the Popple River Fixed Site. Iron concentrations ranged from $150 \mu \mathrm{g} / \mathrm{L}$ to $740 \mu \mathrm{g} / \mathrm{L}$, and the median concentration was $320 \mu \mathrm{g} / \mathrm{L}$. In general, iron concentrations increased during periods of increased streamflow.

\section{Pensaukee River near Krakow, Wis.}

The Pensaukee River near Krakow, Wis., drains $93 \mathrm{~km}^{2}$ of primarily agricultural land northwest of the city of Green Bay, Wis. Downstream, the Pensaukee empties into Green Bay. Land use in the Pensaukee River Basin is primarily agricultural and includes small grains and forage crops, pasture, and commercial vegetables. Scattered throughout the basin are small wetlands that make up slightly more than 9 percent of the total land area. Tightly packed surficial deposits of loam limit infiltration and ground-water discharge to the stream, resulting in widely fluctuating streamflows. Above-normal precipitation in April through July 1993 resulted in the highest mean daily streamflow during the study period. Most of the storm samples were collected at the Pensaukee River site during this time period. Normal precipitation in spring 1995 was followed by below-normal precipitation in June and July. A period of backwater, and very low to zero flow, was observed during June and July 1995 due to a large beaver dam downstream of the 

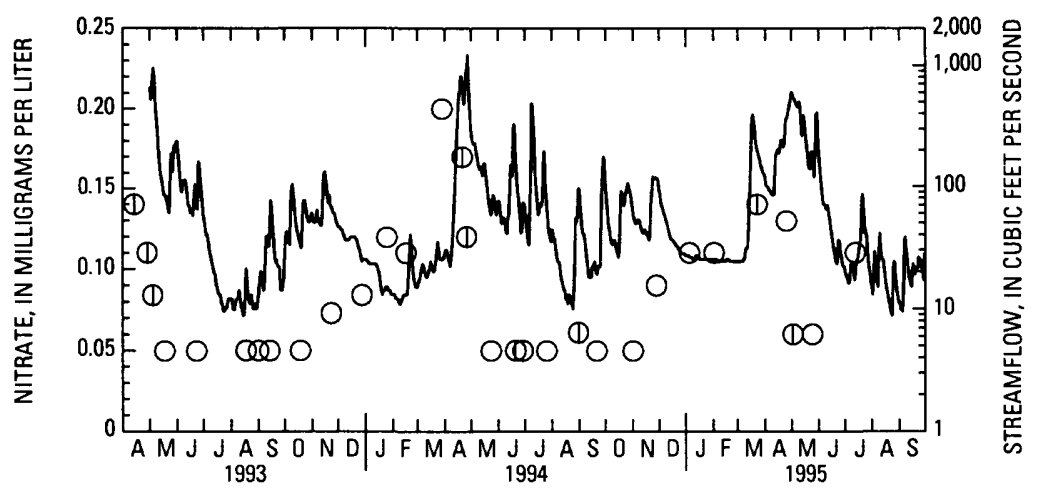

EXPLANATION

- Streamflow

Routine sample

$\ominus$ Concentrations

below Method

Detection Limit

(MDL)

(1) Storm sample

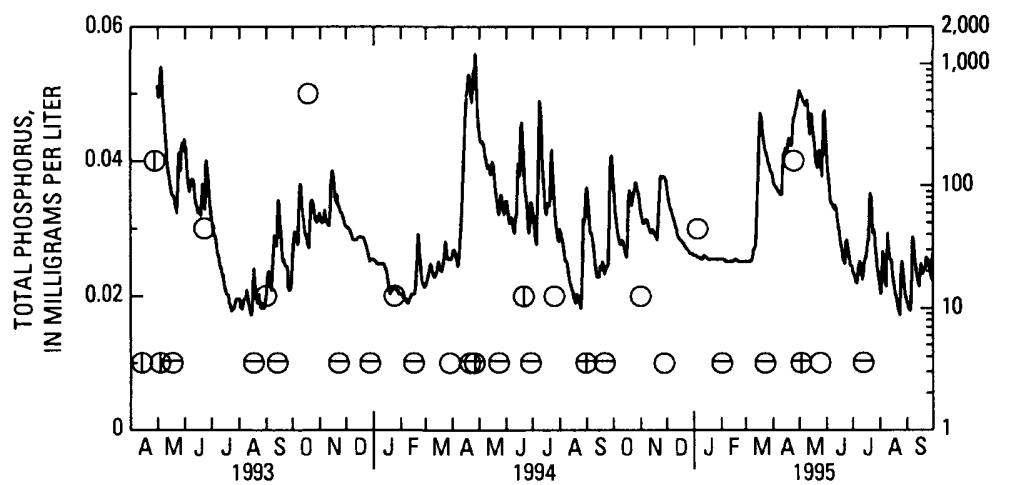

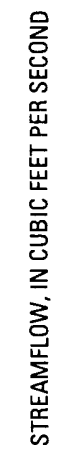
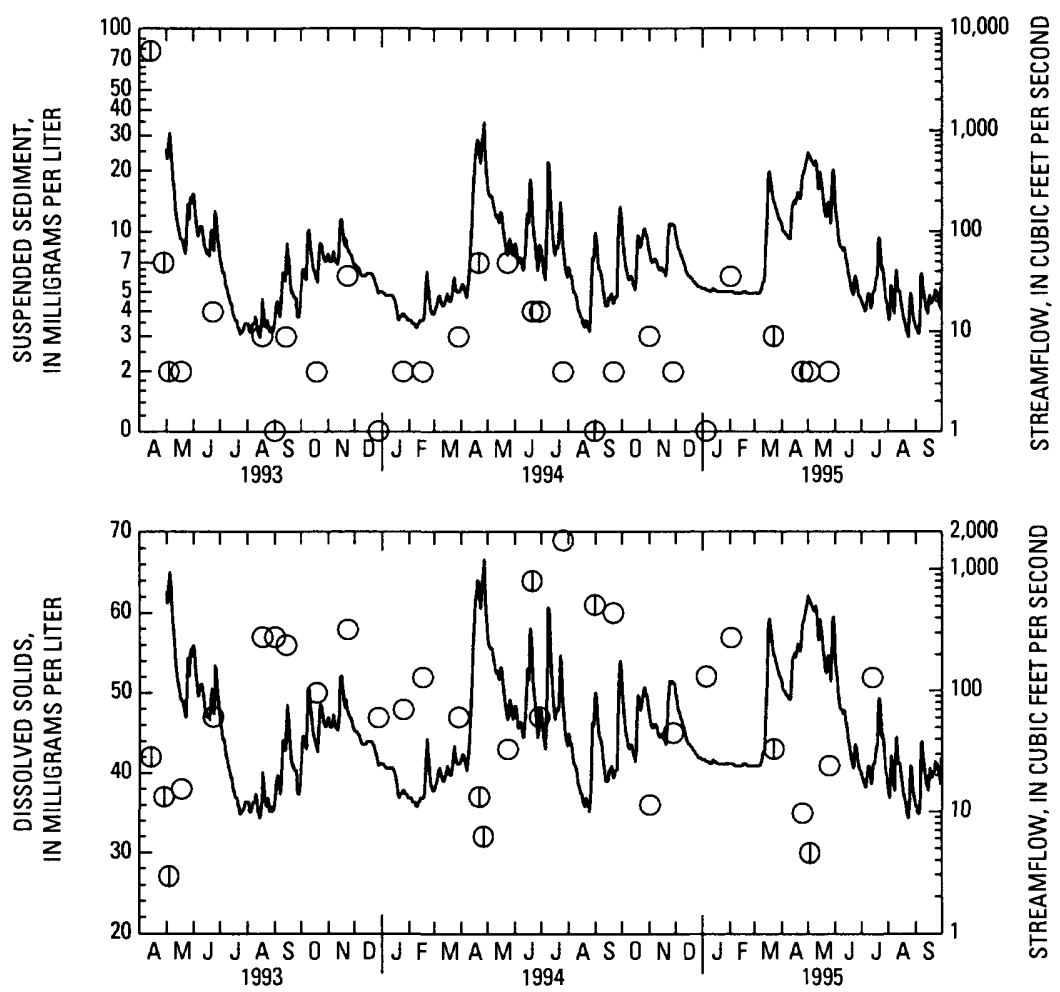

Figure 5. Streamflow and instantaneous concentrations of nitrate, total phosphorus, suspended sediment, and dissolved solids, at the Peshekee River near Martins Landing, Mich. Streamflow data were collected downstream at Peshekee River near Michigamme, Mich. 

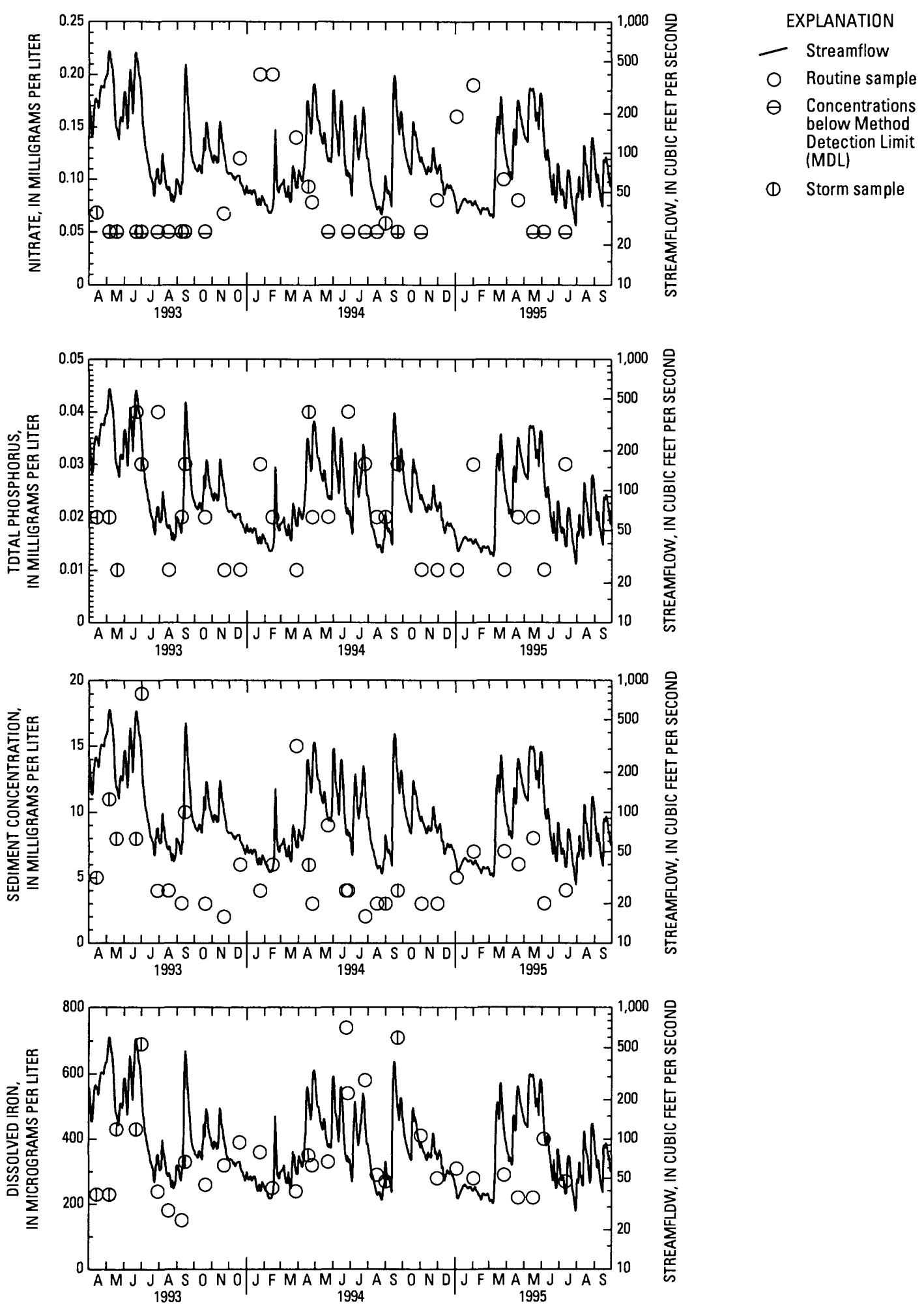

Figure 6. Streamflow and instantaneous concentrations of nitrate, total phosphorus, sediment concentration, and dissolved iron at the Popple River near Fence, Wis. 
wading section. Large algal blooms were noted during the summer months of each year.Thirty-four water samples were collected at this site during the study period (fig. 7).

Nitrate concentrations ranged from below the 0.05 $\mathrm{mg} / \mathrm{L} \mathrm{MDL}$ to $5.0 \mathrm{mg} / \mathrm{L}$. The median nitrate concentration of $0.78 \mathrm{mg} / \mathrm{L}$ was similar to the $0.72 \mathrm{mg} / \mathrm{L} \mathrm{NMC}$ in agricultural areas (Smith and others, 1993). Nitrate concentrations were higher during October through April. The sample with the highest nitrate concentration ( 5 $\mathrm{mg} / \mathrm{L}$ ) was collected in March 1995, during spring breakup. Sampled nitrate concentrations were highest during the cold-water months possibly due to (a) reduced consumption of the nitrate by aquatic organisms, (b) proportionally, ground-water recharge is the major source of flow, (c) reduced water temperatures, or (d) a combination of these factors.

Total-phosphorus concentrations at the Pensuakee River site ranged from 0.040 to $1.2 \mathrm{mg} / \mathrm{L}$. The median concentration of $0.165 \mathrm{mg} / \mathrm{L}$ is similar to the $0.23 \mathrm{mg} / \mathrm{L}$ NMC (Smith and others, 1993). The USEPA recommends that total-phosphorus concentration not exceed $0.10 \mathrm{mg} / \mathrm{L}$ in flowing water to discourage excessive aquatic growth.The median concentration at this site $(0.165 \mathrm{mg} / \mathrm{L})$ exceeded the U.S. Environmental Protection Agency (USEPA) suggested upper concentration of $0.10 \mathrm{mg} / \mathrm{L}$. The highest total-phosphorus concentrations were observed during the growing season. The highest observed concentration of total phosphorus (1.2 $\mathrm{mg} / \mathrm{L}$ ) was in a sample collected during a period of very low flow when the stream was backed up through the sampling reach by a beaver dam downstream. These data indicate that phosphorus may be leaching from the sediments and is usually diluted during periods of flowing water. Large macrophyte (duckweed) blooms were observed during periods of low flow in the summer of 1995 through the sampling reach.

Suspended-sediment concentrations ranged from 4 $\mathrm{mg} / \mathrm{L}$ to $166 \mathrm{mg} / \mathrm{L}$, with a median concentration of 22.5 $\mathrm{mg} / \mathrm{L}$. The highest measured suspended-sediment concentrations occurred during periods of elevated streamflow.

Dissolved-calcium concentrations tended to be highest in areas underlain by carbonate bedrock. Carbonate bedrock underlies the Pensaukee River Basin; thus, calcium was selected as the discriminator characteristic at this site. Calcium concentrations ranged from 18 to $40 \mathrm{mg} / \mathrm{L}$; the median concentration was $77 \mathrm{mg} / \mathrm{L}$. The highest calcium concentrations observed were dur- ing the winter months, when the flows were low and surface runoff was insignificant. Samples collected during high flows had the lowest calcium concentrations. These data suggest that the carbonate bedrock may be the principal source of calcium at Pensaukee River site.

\section{Duck Creek at Seminary Road near Oneida, Wis.}

Duck Creek near Oneida, Wis., drains $247 \mathrm{~km}^{2}$ of primarily agricultural land in east-central Wisconsin. Downstream, Duck Creek discharges into lower Green Bay immediately outside of the city of Green Bay, Wis. Most of the land in the Duck Creek Basin is within the Reservation of the Oneida Nation of Native Americans. The Oneida Nation has developed a 150year plan for the watershed, including measures for extensive rehabilitation of the stream corridor, erosion control, integrated pest management, organic farming, and other means to improve the water quality and the biotic integrity of the stream. Additional information on the 150-year plan is presented in Finney (1995). The Duck Creek Basin was declared a Priority Watershed in 1995 (Wisconsin Department of Natural Resources, 1994). Fifty-six water samples were collected at the Duck Creek site during the study period (fig. 8). Duck Creek is generally a turbid, slowmoving stream draining farmlands that are primarily in corn production and pastureland for dairy cattle operations. The tightly packed clay surficial deposits in the basin limit infiltration, resulting in mostly surface runoff. Streamflow reacts rapidly to rainfall and runoff. During dry periods, streamflow is low to nonexistent due to little ground-water discharge. Abovenormal precipitation occurred during April through July 1993. Below-normal precipitation during June and July 1995 resulted in little to no flow during part of June and most of July 1995. Discharge was measured downstream from the sampling site at Duck Creek near Howard, Wis. Storm-runoff samples were collected during each of the three growing seasons.

Nitrate concentrations ranged from below the $0.50 \mathrm{mg} / \mathrm{L} \mathrm{MDL}$ to a maximum of $6.30 \mathrm{mg} / \mathrm{L}$. The median concentration of $1.55 \mathrm{mg} / \mathrm{L}$ was more than double the $0.72 \mathrm{mg} / \mathrm{L}$ NMC for agricultural areas (Smith and others, 1993). The highest concentrations of nitrate were in samples collected during periods of 

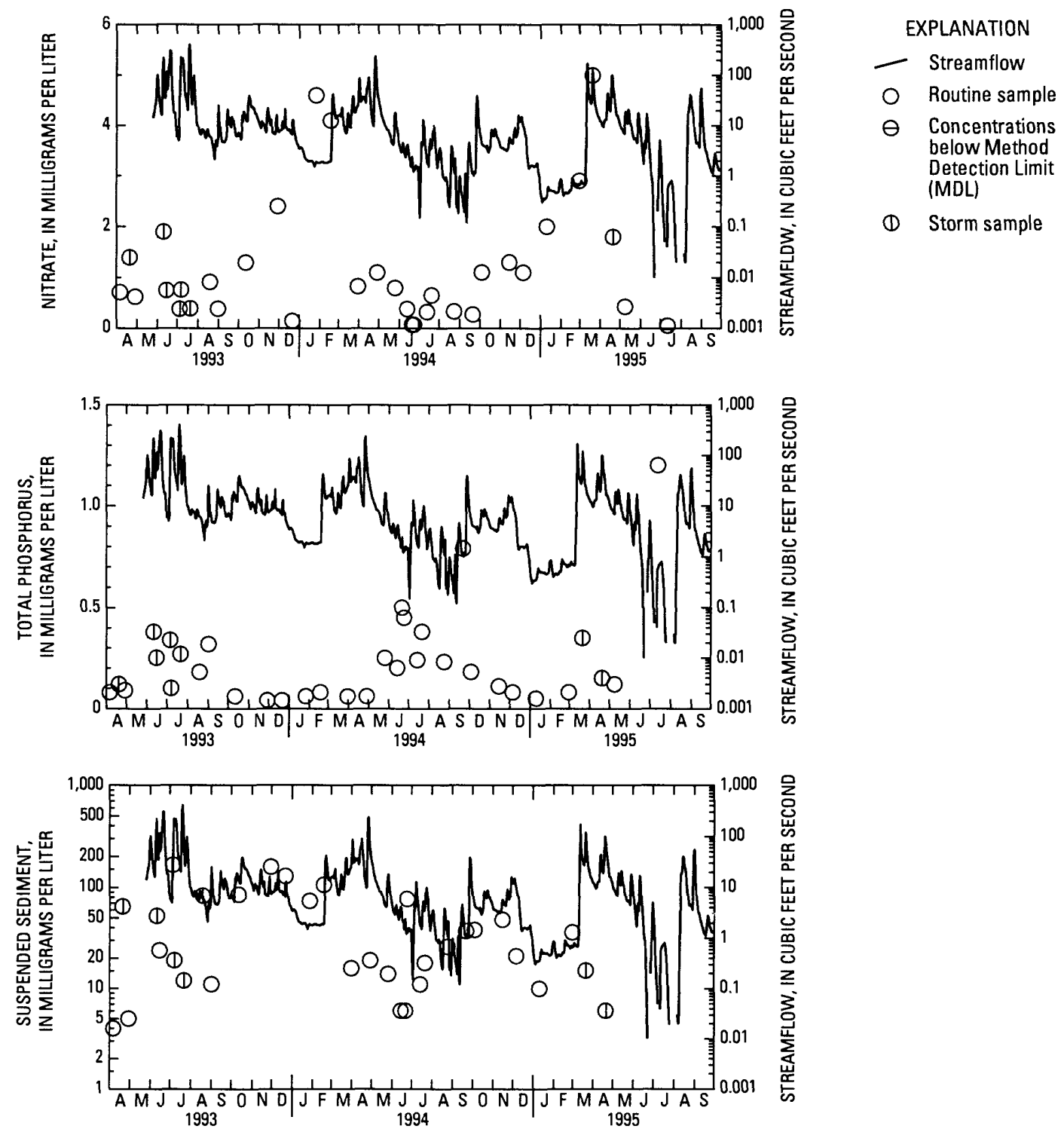

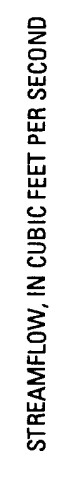

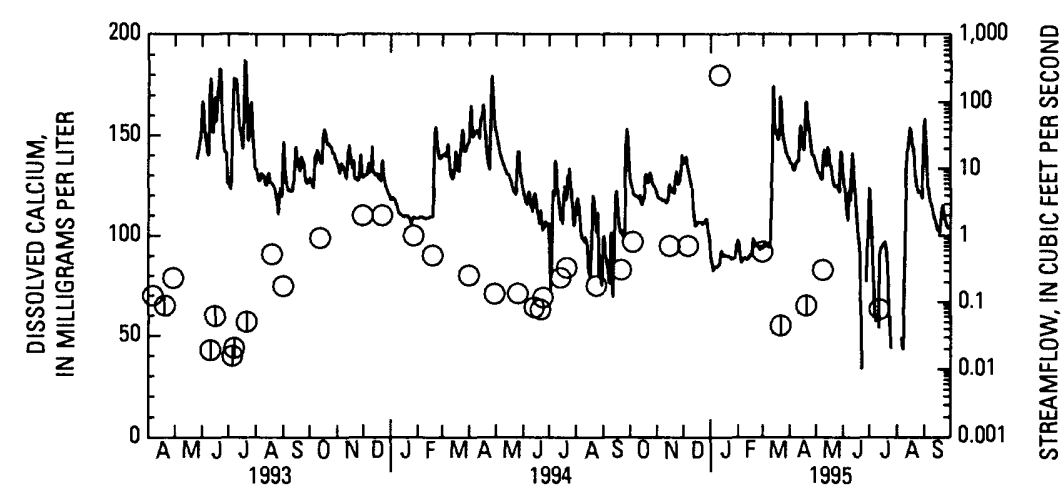

Figure 7. Streamflow and instantaneous concentrations of nitrate, total phosphorus, suspended sediment, and dissolved calcium, at the Pensaukee River near Krakow, Wis. 

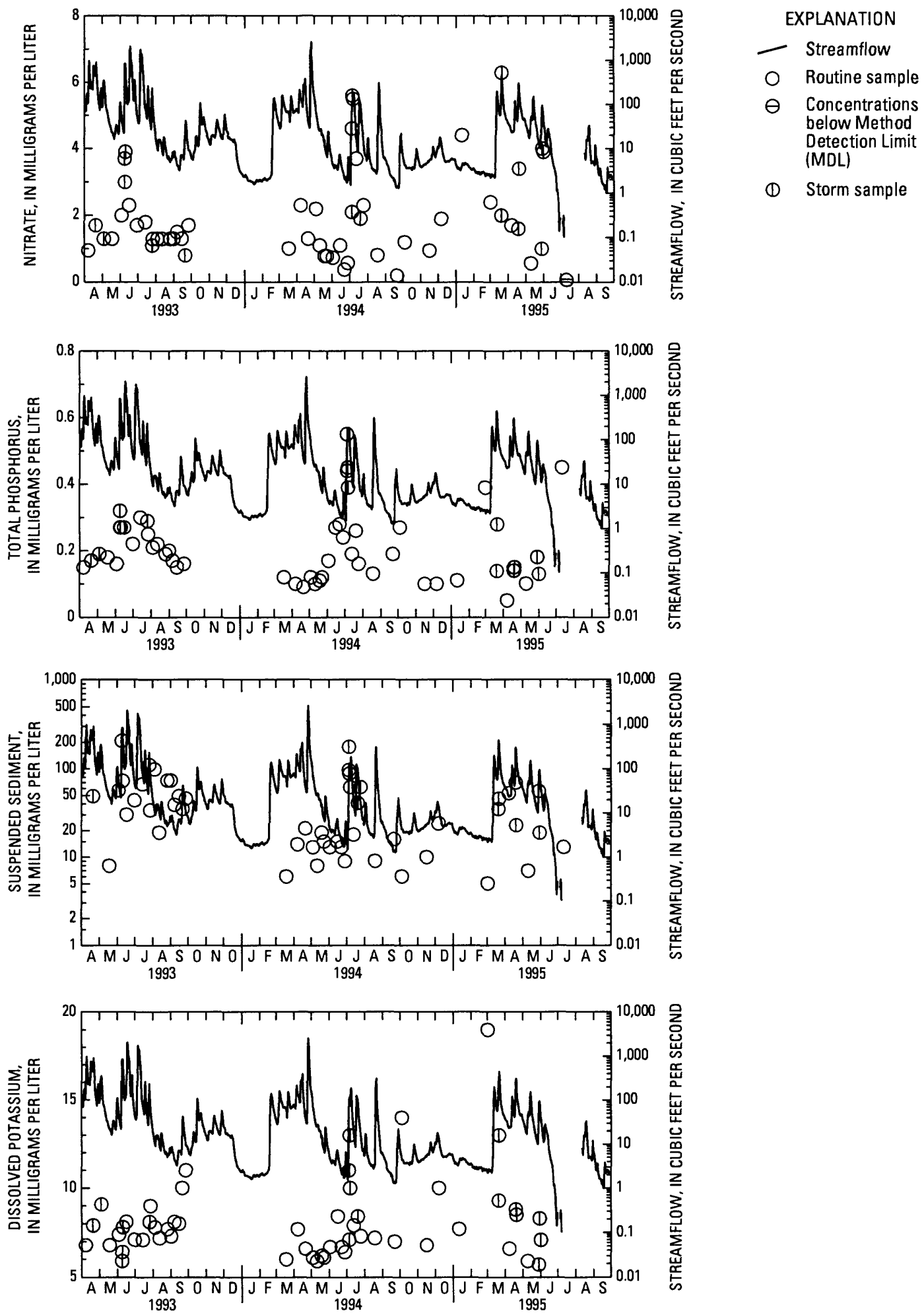

Figure 8. Streamflow and instantaneous concentrations of nitrate, total phosphorus, suspended sediment, and dissolved potassium, at Duck Creek at Seminary Road near Oneida, Wis. Daily discharge data were collected at Duck Creek near Howard, Wis. downstream from sampling site. 
high streamflow; the highest observed concentrations were in samples collected during the first major runoff event in March 1995.

Total-phosphorus concentrations ranged from 0.05 to $0.55 \mathrm{mg} / \mathrm{L}$. The median concentration of $0.18 \mathrm{mg} / \mathrm{L}$ was similar to the $0.23 \mathrm{mg} / \mathrm{L} \mathrm{NMC} \mathrm{(table} \mathrm{4)} \mathrm{and}$ exceeded the $0.10 \mathrm{mg} / \mathrm{L}$ USEPA suggested limit for total phosphorus. The data indicate a seasonality in concentrations, with the higher concentrations being found during the growing season and during high flow sampling events. The highest concentration of total phosphorus was found in a July 1994 storm sample. The highest observed concentration $(0.5 \mathrm{mg} / \mathrm{L})$ for a nonevent sample was in a sample collected from ponded water during a period of no flow, probably an indication that phosphorus may always be leaching from the bottom sediments, but is usually diluted by flowing water.

Suspended-sediment concentrations ranged from 5 $\mathrm{mg} / \mathrm{L}$ to a maximum of $207 \mathrm{mg} / \mathrm{L}$; the median concentration was $34 \mathrm{mg} / \mathrm{L}$. Increased suspended-sediment concentrations occurred during high-flow events and were associated with increased total-phosphorus concentrations.

In soils potassium is commonly present in clay minerals (Hem, 1985). Because of the clayey surficial deposits in the Duck Creek Basin, dissolved potassium was selected as the discriminator characteristic. At the Duck Creek Fixed Site, dissolved potassium ranged from 5.7 to $19 \mathrm{mg} / \mathrm{L}$; the median concentration was 7.7 $\mathrm{mg} / \mathrm{L}$. There was no apparent seasonal variability, and generally, concentrations of potassium were elevated during high-flow events. The highest dissolved potassium concentration was found in a sample collected under ice cover in early March 1995. The East River near De Pere, Wis., is the only other Fixed Site where the median potassium concentration $(7.6 \mathrm{mg} / \mathrm{L})$ was similar to that at Duck Creek.

\section{Tomorrow River near Nelsonville, Wis.}

The Tomorrow River near Nelsonville, Wis., drains $114 \mathrm{~km}^{2}$ in the eastern part of the Study Unit in the Fox River Basin. The land use is a mixture of pasture, croplands, and forest. Forests and wetlands are more common near the Fixed Site than in the headwaters area, where land use is predominantly row crops and pasture. The Tomorrow River is a coldwater, tannin-stained, sand-bottom stream with a naturally-reproducing trout population. Much of the land along the stream corridor near the Fixed Site is controlled by the WDNR as public hunting and fishing ground. The Tomorrow River Basin is an area of highly permeable, sandy surficial deposits. The Tomorrow River Basin was declared a Priority Watershed by the WDNR in 1995 primarily because of high nitrate concentrations in ground water. Flow in the Tomorrow River is fairly uniform because of substantial ground-water recharge and the capacity of the wetlands to buffer extremes in flow. Precipitation of 5 to 10 $\mathrm{cm}$ above average monthly means in the spring of 1993 (April-June) contributed to the highest daily mean discharge for the study period. Most of the high-flow samples were collected at the Tomorrow River site during this time period. Thirty-two water samples were collected at the site during the study period (fig. 9).

Nitrate concentrations ranged from 0.62 to 3.10 $\mathrm{mg} / \mathrm{L}$; the median concentration of $1.85 \mathrm{mg} / \mathrm{L}$ was more than twice the $0.72 \mathrm{mg} / \mathrm{L} \mathrm{NMC} \mathrm{(table} \mathrm{4).} \mathrm{The} \mathrm{highest}$ concentrations of nitrate were found during the winter months, when surface runoff was minimal, and base flow was maintained primarily by ground-water discharge. The lowest nitrate concentrations occurred during spring when increased flow dilutes the groundwater input. These data indicate a seasonality in nitrate concentration, and the concentrations of nitrate detected support the ground-water/land-use survey data that highest median nitrate concentrations were found at this site. Additional information on nitrate in ground water can be found in Saad (1994).

Total-phosphorus concentrations ranged from less than the $0.010 \mathrm{mg} / \mathrm{L} \mathrm{MDL}$ to $0.30 \mathrm{mg} / \mathrm{L}$; the median concentration was $0.02 \mathrm{mg} / \mathrm{L}$. Two samples had totalphosphorus concentrations that exceeded $0.10 \mathrm{mg} / \mathrm{L}$, the USEPA suggested limit for flowing waters. The median concentration was similar to the $0.05 \mathrm{mg} / \mathrm{L}$ NMC for forested areas and was an order of magnitude less than the $0.23 \mathrm{mg} / \mathrm{L} \mathrm{NMC}$ for agricultural areas (table 4). The highest total-phosphorus concentration $(0.3 \mathrm{mg} / \mathrm{L})$ was observed in June 1993 , during a period of elevated base flow, which possibly indicates that previous rains had saturated the ground and surficial runoff carried nutrients off the fields. The median phosphorus concentration was similar to that of the forested Fixed Sites (Peshekee, Menominee, and Popple River), and was lower than the median concentrations at the remaining Fixed Sites.

Suspended-sediment concentrations ranged from 3 to $113 \mathrm{mg} / \mathrm{L}$, with a median concentration of $8 \mathrm{mg} / \mathrm{L}$. The highest sampled concentrations occurred in baseflow samples. Concentrations were higher than at the 

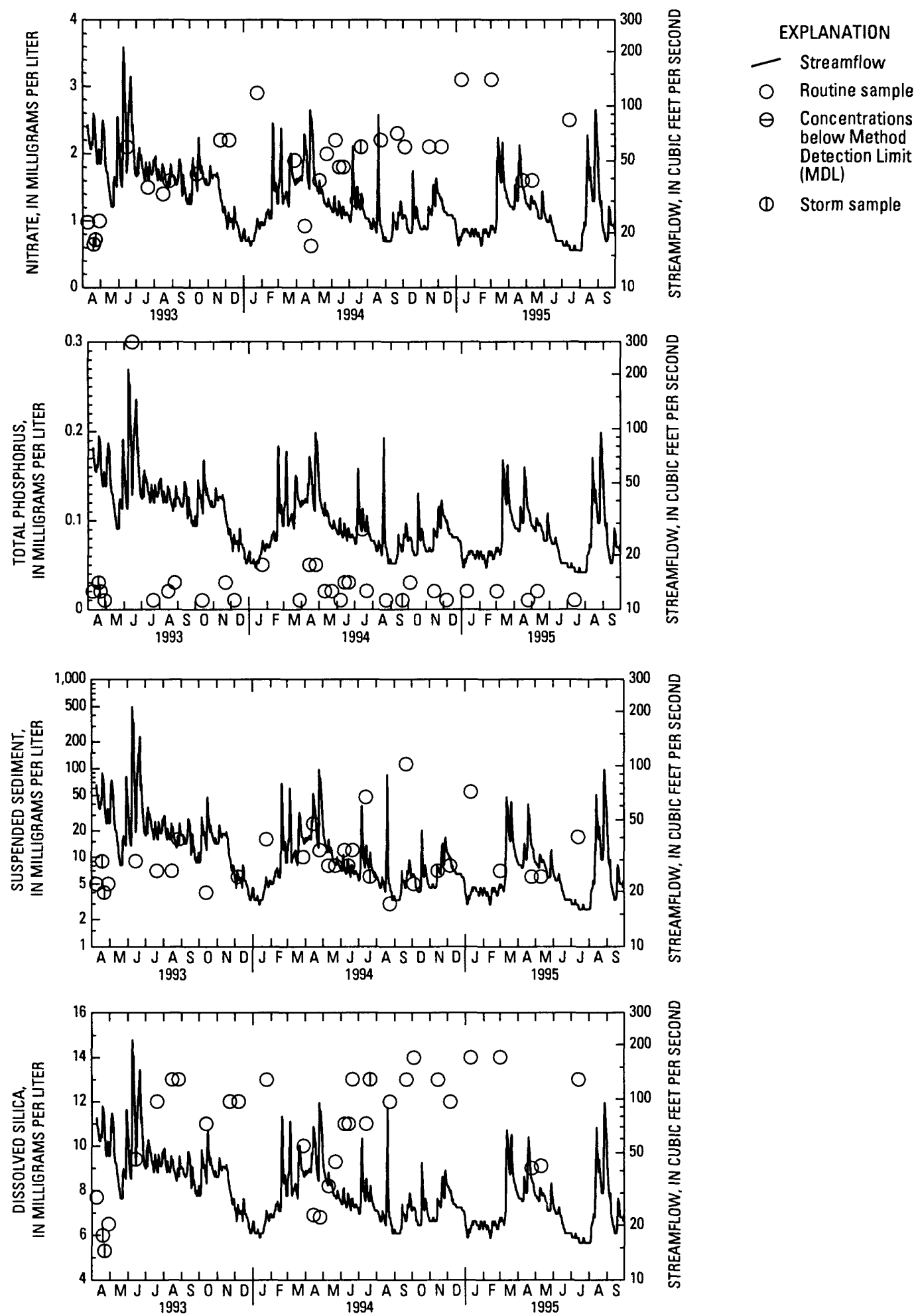

Figure 9. Streamflow and instantaneous concentrations of nitrate, total phosphorus, suspended sediment, and dissolved silica at the Tomorrow River near Nelsonville, Wis. 

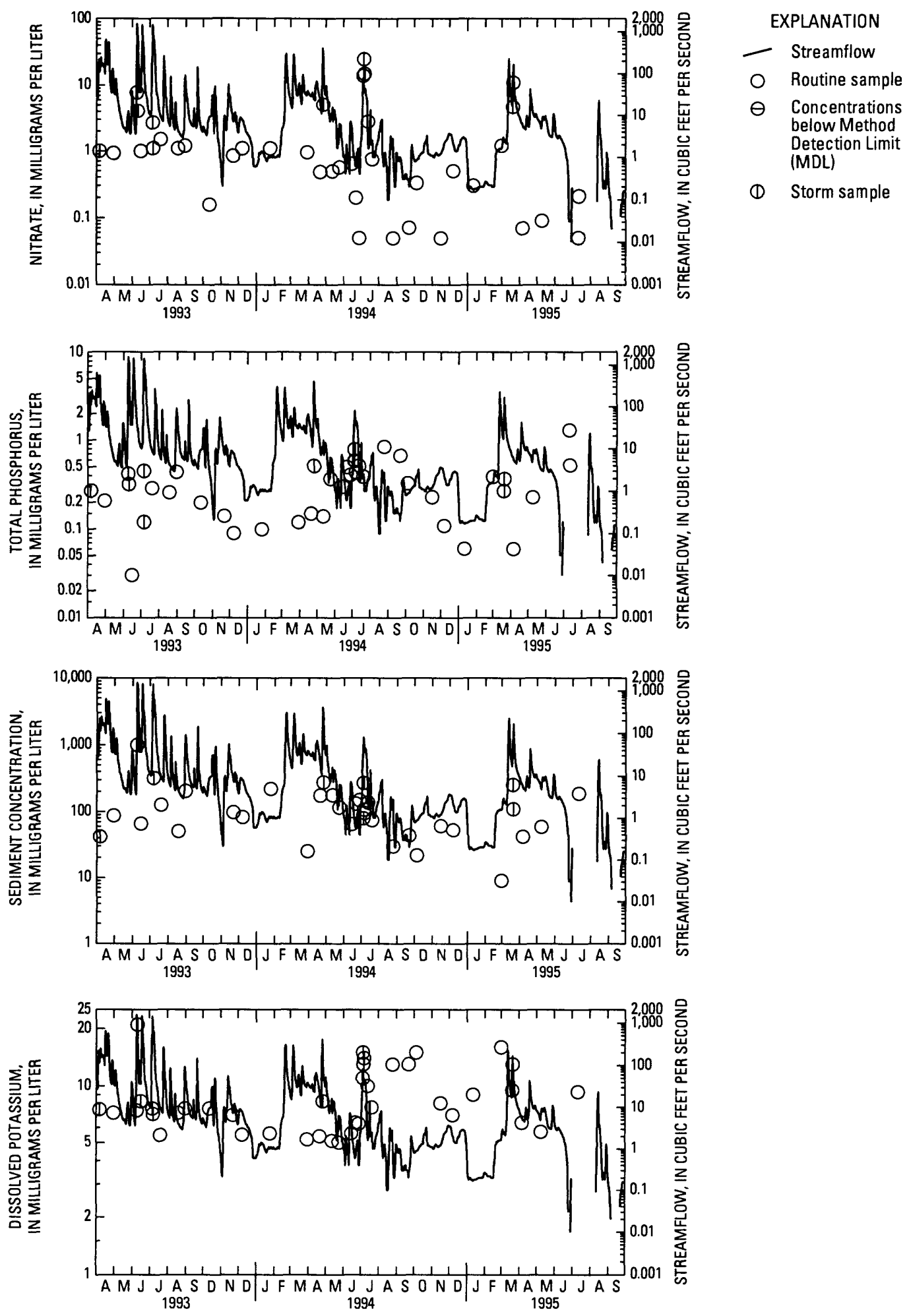

Figure 10. Streamflow and instantaneous concentrations of nitrate, total phosphorus, suspended sediment, and dissolved potassium at the East River at Midway Rd. near De Pere, Wis. Daily discharges for April 5-6 and Sept. 8-30, 1994, are estimated based on comparison using ESTWAT with nearby gaging stations. ESTWAT compares discharges at sites with similar drainages and estimates discharge during missing periods. Daily discharges for the period of April 7 to Sept. 7, 1994 are based upon observer readings at East River at County Hwy. ZZ near Greenleaf, Wis., approximately 1.4 river miles upstream. 
Peshekee and Popple River sites, and significantly lower than those at the remaining indicator sites.

The highest observed silica concentrations were found at sites with sandy surficial deposits typical of the Tomorrow River Basin; therefore, silica was selected as the discriminator characteristic for this site. Concentrations ranged from 5.3 to $14.0 \mathrm{mg} / \mathrm{L}$; the median concentration was $11.5 \mathrm{mg} / \mathrm{L}$. Generally, the highest sampled silica concentrations occurred during periods of lower flows. The median silica concentration was similar to that at the North Branch Milwaukee (11.0 mg/L), Popple $(9.10 \mathrm{mg} / \mathrm{L})$, and Pensaukee $(9.20 \mathrm{mg} / \mathrm{L})$ River Fixed Sites. Sand or loam were the primary surficial deposits at each of these sites.

\section{East River at Midway Road near De Pere, Wis.}

The East River near De Pere, Wis., drains $122 \mathrm{~km}^{2}$ of farmland in east-central Wisconsin, near the city of Green Bay, and empties into the Fox River in the city of Green Bay. The East River Basin has the highest percentage of agricultural land of any Fixed Site. Farming in the basin consists of row-crop production and pastures in support of family and commercial farm operations. The river is generally a slow-moving, meandering, turbid stream. Large amounts of suspended-sediment (clay) particles are evident in the water throughout the year. Because the clayey surficial deposits of the basin limit infiltration, the river is subject to rapid fluctuations in stage during rainfall events and periods of no flow during extended dry weather. Because of bridge demolition and construction of a new bridge at the original Fixed Site, discharge and water-quality data were collected 2.2 river kilometers upstream from the Fixed Site from April through September 1994. On October 1, 1994, a new stream gage was installed at the original Fixed-site location. Above-average precipitation from April through June 1993 (5.1 to $10.2 \mathrm{~cm}$ above normal monthly means) contributed to the highest mean daily discharge for the study period. Half of all storm samples at the East River Fixed Site ( 5 of 10 ) were collected during this period. The East River has been a Priority Watershed since 1986 (Wisconsin Department of Natural Resources, 1994). Forty water samples were collected at the East River Fixed Site during the study period (fig. 10).

Nitrate concentrations ranged from below the 0.05 $\mathrm{mg} / \mathrm{L} \mathrm{MDL}$ to a maximum of $25 \mathrm{mg} / \mathrm{L}$. The median concentration of $0.945 \mathrm{mg} / \mathrm{L}$ was similar to the $0.72 \mathrm{mg} / \mathrm{L}$
NMC (table 4). The USEPA Maximum Contaminant Level (MCL) for nitrate in drinking water is $10 \mathrm{mg} / \mathrm{L}$. Observed concentrations of nitrate exceeded the MCL in three high-flow samples in July 1994 and March 1995. The highest observed concentrations were found in high-flow samples, either during spring ice breakup or during the first runoff event during the growing season. These data indicate that potential sources of nitrates are manure spread on fields during winter months and fertilizers applied to row crops during the growing season.

Concentrations of total phosphorus ranged from 0.03 to $1.30 \mathrm{mg} / \mathrm{L}$; the median concentration of 0.32 $\mathrm{mg} / \mathrm{L}$ was similar to the $0.23 \mathrm{mg} / \mathrm{L} \mathrm{NMC} \mathrm{(table} 4$ ) and exceeds the $0.10 \mathrm{mg} / \mathrm{L}$, USEPA suggested limit for flowing waters. Total-phosphorus concentrations were significantly higher than those at all other Fixed Sites. The highest concentration $(1.30 \mathrm{mg} / \mathrm{L})$ was in a sample collected from ponded water during a period of no flow, probably an indication that phosphorus may always be leaching from bottom sediments but usually is diluted by flowing water.

Suspended-sediment concentrations ranged from 9 to $1,000 \mathrm{mg} / \mathrm{L}$; the median concentration was 97 $\mathrm{mg} / \mathrm{L}$. Higher concentrations occurred during highflow events and the highest sampled concentration occurred during a high-flow event in June 1993.

Potassium concentrations in the East River were among the highest at all Fixed Sites. The concentration of dissolved potassium at the East River site ranged from 5.0 to $21 \mathrm{mg} / \mathrm{L}$; the median concentration was $7.6 \mathrm{mg} / \mathrm{L}$. The highest concentration of potassium occurred during a runoff event in June 1993. Potassium concentrations at the East River were similar to those at the Duck Creek Fixed Site (both basins are underlain by clayey surficial deposits) and were significantly higher than those at the remaining Fixed Sites. Streams draining clayey surficial deposits appear to have the highest potassium concentrations.

\section{North Branch Milwaukee River near Random Lake, Wis.}

The North Branch Milwaukee River Fixed Site drains $133 \mathrm{~km}^{2}$ of primarily agricultural land into the Milwaukee River in the southeastern part of the Study Unit. Agriculture in the basin consists of pasture and row-crop production. A 50-meter-wide area of undisturbed vegetation borders both sides of the river near 
the site. Within the North Branch Milwaukee River Basin, permeable surficial deposits permit rapid infiltration of precipitation and thus buffer extremes in streamflow. River characteristics vary widely within the basin, from a coldwater trout stream in headwater areas to a warmwater stream near the Fixed Site. Most storm samples at this site were collected during spring and summer of 1993. The North Branch Milwaukee River Basin has been a Priority Watershed since 1984 (Wisconsin Department of Natural Resources, 1994). Forty-five water samples were collected at the North Branch Milwaukee River Fixed Site during the study period (fig. 11).

Nitrate concentrations ranged from below the 0.05 $\mathrm{mg} / \mathrm{L} \mathrm{MDL}$ to $3.60 \mathrm{mg} / \mathrm{L}$; the median nitrate concentration, $1.60 \mathrm{mg} / \mathrm{L}$, was twice the $0.72 \mathrm{mg} / \mathrm{L} \mathrm{NMC}$ for agricultural areas (table 4). The minimum measured nitrate concentration is uncertain; nitrate concentrations 10 days before the minimum value, and 5 days after, were two orders of magnitude larger than the minimum value, with no increase or decrease in discharge. In general, concentrations varied only slightly throughout the sampling period. Nitrate concentrations at this site were similar to those at the Tomorrow River and Duck Creek Fixed Sites, and significantly higher than those at the remaining Fixed Sites.

Total-phosphorus concentrations at this site ranged from 0.03 to $0.42 \mathrm{mg} / \mathrm{L}$; the median concentration, $0.140 \mathrm{mg} / \mathrm{L}$ was similar to the $0.23 \mathrm{mg} / \mathrm{L}$ NMC (table 4) and exceeded $0.10 \mathrm{mg} / \mathrm{L}$ USEPA suggested limit. The data indicate a seasonality in total-phosphorus concentrations, with the highest concentrations being observed during the growing season, when algal blooms were observed. Total-phosphorus concentrations were similar to those at the Pensaukee River and at Duck Creek, and significantly lower than those at the East River Fixed Site. In general, phosphorus concentrations were highest at Fixed Sites within agricultural areas.

Suspended-sediment concentrations ranged from 6 to $480 \mathrm{mg} / \mathrm{L}$, with a median concentration of $54 \mathrm{mg} / \mathrm{L}$. The highest concentration sampled occurred during a high-flow event in April 1993. In general, phosphorus and suspended-sediment concentrations were correlated. Generally, suspended-sediment concentrations were fairly consistent during the growing season.

The median silica concentration was relatively high at the North Branch Milwaukee River Fixed Site compared to the other Fixed Sites. Silica was selected as the discriminator characteristic at the North Branch site, and concentrations ranged from 0.17 to $17.0 \mathrm{mg} / \mathrm{L}$; the median concentration was $11.0 \mathrm{mg} / \mathrm{L}$. The minimum observed concentration $(0.17 \mathrm{mg} / \mathrm{L})$ on May 18,1994 , is questionable; silica concentrations 6 days before and 6 days after the observed minimum were an order of magnitude higher $(5.7 \mathrm{mg} / \mathrm{L}$ and $9.3 \mathrm{mg} / \mathrm{L}$, respectively). Silica concentrations varied little with season, or with streamflow. Except for the Tomorrow River $(11.5 \mathrm{mg} / \mathrm{L})$ and Pensaukee River $(9.2 \mathrm{mg} / \mathrm{L})$ Fixed Sites, silica concentrations at the North Branch Milwaukee River Fixed Site were significantly higher than those at all other agricultural indicator sites. Silica concentrations at the North Branch Milwaukee River Fixed Site were similar to median concentrations at the other sites where sandy surficial deposits predominate. The data indicate that the type of surficial deposits may be the factor that most affects silica concentrations in streamwater.

\section{Lincoln Creek at 47th Street at Milwaukee, Wis.}

Lincoln Creek at Milwaukee, Wis., is a small urban stream with a $25 \mathrm{~km}^{2}$ drainage area, emptying into the Milwaukee River. Large parts of the channel of Lincoln Creek are lined with concrete, and flows are controlled by a series of weirs. Runoff from large areas of impermeable concrete and asphalt in the basin causes extremely rapid changes in stage during rainfall and snowmelt events. Many storm sewers flow directly into Lincoln Creek. Because of the "flashiness" of the stream, a data smoothing technique (9-day moving average) was applied to the streamflow data to smooth and dampen gage-height spikes (fig. 12). Low flow is maintained by ground-water discharge. Lincoln Creek has been a Priority Watershed since 1994 (Wisconsin Department of Natural Resources, 1994). Thirty water samples were collected at Lincoln Creek during the study period.

Nitrate concentrations ranged from 0.23 to $2 \mathrm{mg} / \mathrm{L}$; the median concentration of $0.54 \mathrm{mg} / \mathrm{L}$ was similar to the NMC for urban areas (table 4). Nitrate concentrations from two different storm events (August 1993 and June 1994) indicate that nitrate concentrations of Lincoln Creek increase on the rising limb of the storm hydrograph, and decrease on the falling limb. In general, the highest observed nitrate concentrations were found during high-flow events. An especially high nitrate concentration was found in samples collected on the falling limb of a runoff event in April 1993, suggest- 

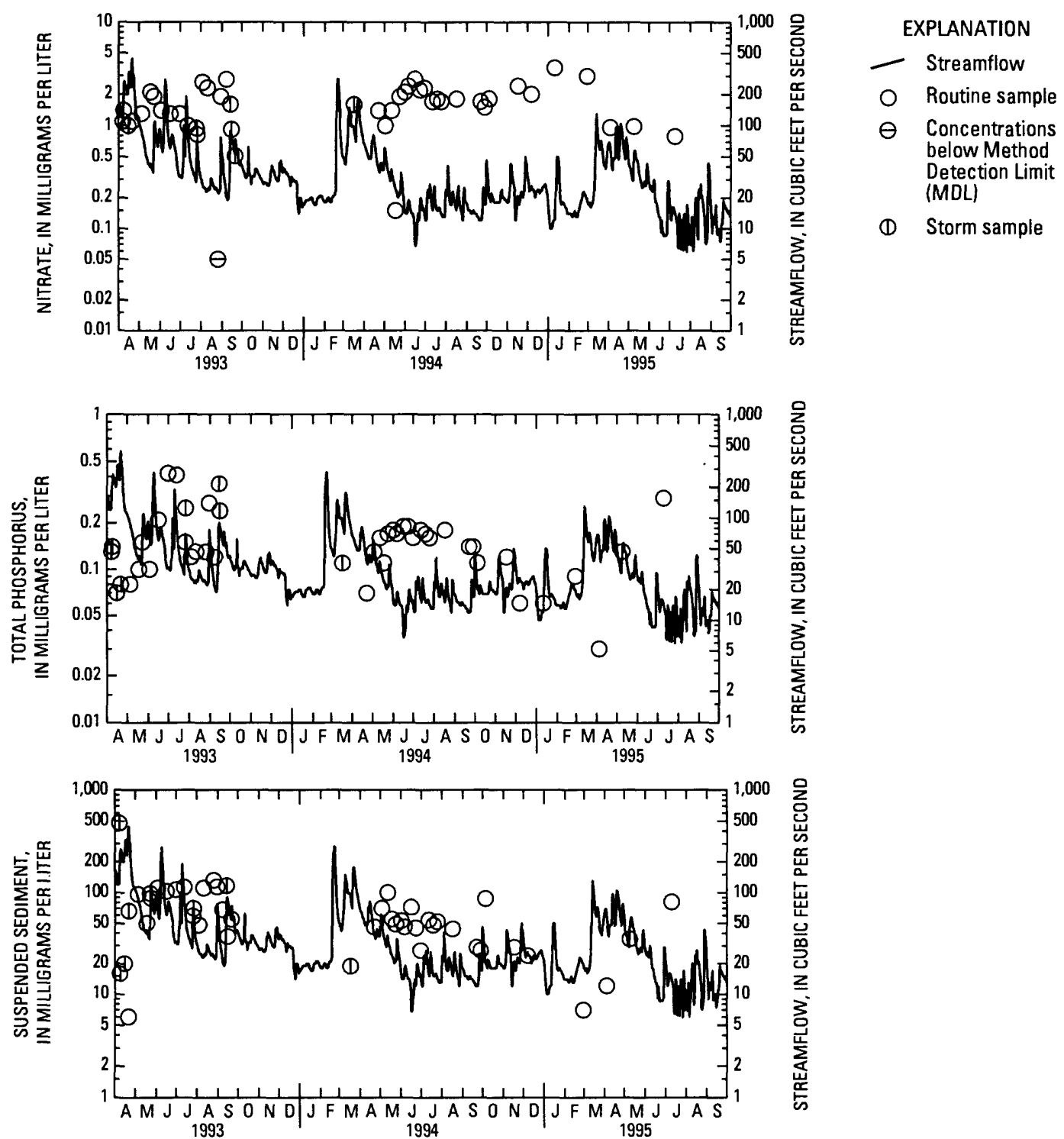

(1) Storm sample

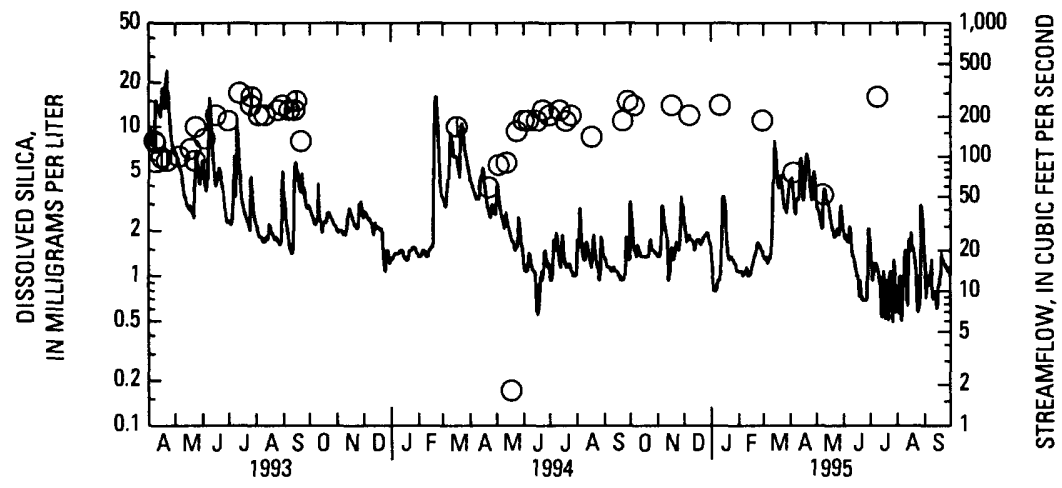

Figure 11. Streamflow and instantaneous concentrations of nitrate, total phosphorus, suspended sediment, and dissolved silica at the North Branch Milwaukee River near Random Lake, Wis. 

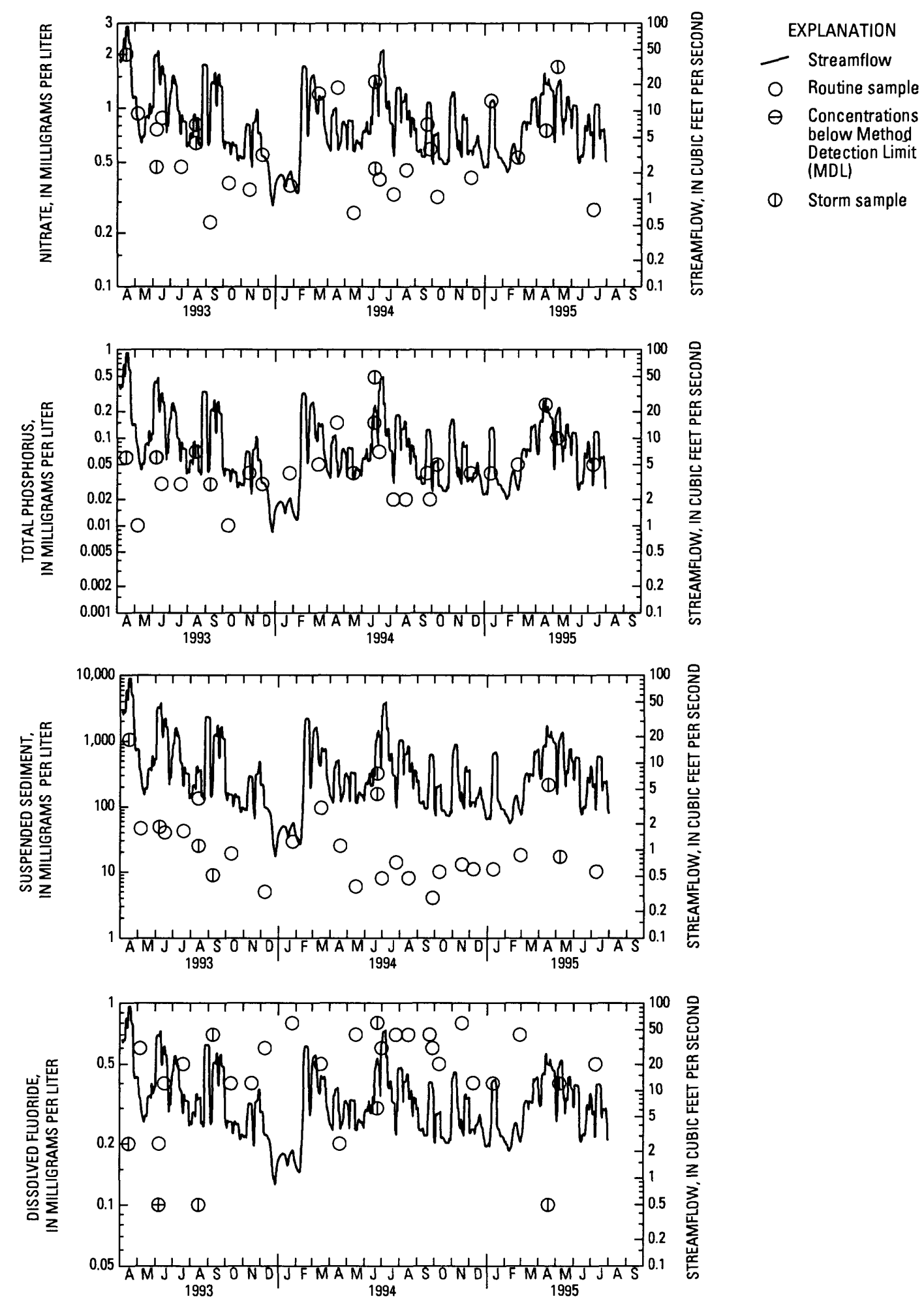

Figure 12. Streamflow and instantaneous concentrations of nitrate, total phosphorus, suspended sediment, and dissolved fluoride at Lincoln Creek at 47 th St. at Milwaukee, Wis. A nine-day smooth has been applied to the daily discharge values. 
ing that concentrations may have been even higher. The data do not indicate any seasonality in nitrate concentrations.

Concentrations of total phosphorus ranged from below the $0.01 \mathrm{mg} / \mathrm{L} \mathrm{MDL}$ to $0.49 \mathrm{mg} / \mathrm{L}$. The median concentration of $0.045 \mathrm{mg} / \mathrm{L}$ was less than the NMC (table 4) and less than $0.10 \mathrm{mg} / \mathrm{L}$ USEPA suggested limit for flowing water. Highest observed phosphorus concentrations were found in June 1994 and May 1995 during high-flow events. The data do not indicate any seasonal pattern in phosphorus concentrations. Concentrations of total phosphorus at the Lincoln Creek Fixed Site were significantly lower than for all agricultural sites with the exception of the Tomorrow River, and were higher than those at the forested indicator sites.

Suspended-sediment concentrations ranged from 4 to $1,050 \mathrm{mg} / \mathrm{L}$; the median concentration was 18.5 $\mathrm{mg} / \mathrm{L}$. The highest sampled concentrations were found in high-flow samples and were associated with high total-phosphorus concentrations. In April 1993, the sampled concentration of $1,050 \mathrm{mg} / \mathrm{L}$ was the highest of any sample collected at any Fixed Site during the study period. In general, higher suspended-sediment concentrations were associated with high-flow events.

Fluoride concentrations at Lincoln Creek were significantly higher than those at all other sites. Fluoride concentrations ranged from below the $0.10 \mathrm{mg} / \mathrm{L} \mathrm{MDL}$ to $0.80 \mathrm{mg} / \mathrm{L}$; the median concentration was $0.50 \mathrm{mg} / \mathrm{L}$. In general, fluoride concentrations in low-flow samples were greater than those in high-flow samples; however, a sample from a high-flow event in June 1994 had the highest concentration. The lowest concentrations of fluoride were also from high-flow samples collected in May and August 1993, and April 1995. These data indicate that a potential source of fluoride could be the upstream discharge of treated water.

\section{WATER QUALITY AT INTEGRATOR SITES}

This section describes water quality, selected natural factors, and land use in the relatively large drainage basins in which the integrator Fixed Sites were located.These sites integrate the effects of natural and human factors on water quality from several RHU's.

\section{Menominee River near McAllister, Wis.}

The Menominee River near McAllister, Wis., drains $10,180 \mathrm{~km}^{2}$ of primarily forested lands over shallow bedrock in northern Wisconsin and the Upper Pen- insula of Michigan. Downstream, the Menominee empties into northern Green Bay at the border cities of Marinette, Wis., and Menominee, Mich. The flow in the lower reaches of the Menominee River is controlled by a series of hydroelectric dams. The drainage area at the Fixed Site accounts for 20 percent of the total drainage area for the Western Lake Michigan Drainages NAWQA Study Unit. Much of the land in the watershed, which is 75 percent forested, is National and State Forests, and State Parks. Agriculture in the basin is limited to small-grain production and pastures in support of family farms. The highest mean daily discharge for the growing season (April through July) for the study period was in spring 1993; the lowest mean daily discharge was in summer 1995. Most of the storm samples collected at the Menominee River Fixed Site were collected during 1993. Twenty-eight water samples were collected at the Menominee River Fixed Site during the study period (fig. 13).

Nitrate concentrations ranged from below the $0.05 \mathrm{mg} / \mathrm{L} \mathrm{MDL}$ to $2.0 \mathrm{mg} / \mathrm{L}$. The median nitrate concentration of $0.096 \mathrm{mg} / \mathrm{L}$ is lower than the NMC (table 4) for both forested and agricultural areas. The highest nitrate concentrations were generally found during winter months, perhaps because of reduced uptake by aquatic organisms during coldwater periods, or due to an increased proportion of the flow from ground-water discharge. Decreased nitrate concentrations during runoff events may be due to the dilution of ground-water discharge. Nitrate concentrations at the Menominee River Fixed Site were significantly lower than at the Milwaukee and Fox River integrator sites. Concentrations were similar to those at the Peshekee and Popple River indicator sites but were significantly lower than concentrations at the remaining Fixed Sites.

Total-phosphorus concentrations ranged from below the $0.01 \mathrm{mg} / \mathrm{L} \mathrm{MDL}$ to $0.04 \mathrm{mg} / \mathrm{L}$; the median concentration of $0.04 \mathrm{mg} / \mathrm{L}$ is similar to the NMC for forested areas (table 4). The highest concentrations of total phosphorus were found during base-flow sampling. No seasonal variation in total-phosphorus concentrations were found. The Menominee River median concentration was below $0.10 \mathrm{mg} / \mathrm{L}$ USEPA suggested limit for flowing waters. Concentrations at the Menominee River integrator site were significantly lower than those at the Fox and Milwaukee River integrator sites. 

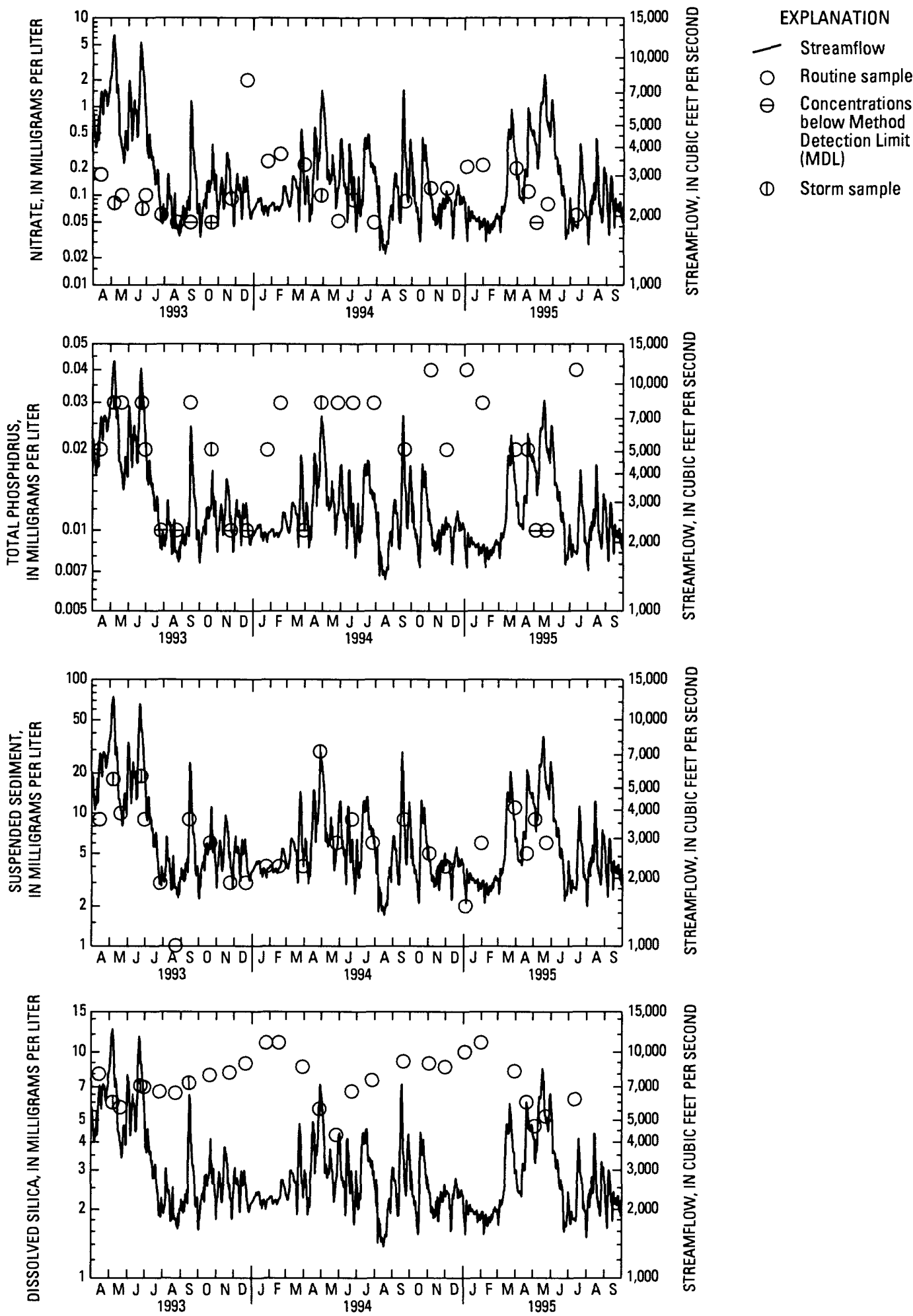

Figure 13. Streamflow and instantaneous concentrations of nitrate, total phosphorus, suspended sediment, and dissolved silica at Menominee River near McAllister, Wis. 
Suspended-sediment concentrations ranged from 1 to $29 \mathrm{mg} / \mathrm{L}$; the median concentration was $6 \mathrm{mg} / \mathrm{L}$. Increased concentrations of suspended sediment were associated with increased streamflow-the highest observed suspended-sediment concentration occurred in a sample collected during a high-flow event in April 1994. In general, the lowest observed concentrations of suspended sediment were associated with lower flows.

Silica was selected as the discriminator characteristic for all three integrator sites. The common factor among the integrator sites is that each of the basins have some area underlain by sandy surficial deposits. The Menominee River drains primarily an area of mixed land use, bedrock, and sandy surficial deposits. Silica concentrations at the Menominee River Fixed Site ranged from 4.3 to $11.0 \mathrm{mg} / \mathrm{L}$; the median concentration was $7.40 \mathrm{mg} / \mathrm{L}$. The higher concentrations of silica in the winter months could (1) indicate that ground water is a principal source of silica at the Menominee River integrator site, (2) be a result of lower water temperatures, or (3) reflect a combination of both factors. Silica concentrations were similar to those at the Milwaukee River fixed integrator site, and significantly higher than those at the mouth of Fox River integrator site.

\section{Mouth of the Fox River at Green Bay, Wis.}

The Fox River at Green Bay, Wis., drains 32 percent of the Western Lake Michigan Drainages Study Unit $\left(16,300 \mathrm{~km}^{2}\right)$. The Wolf River drains $9,560 \mathrm{~km}^{2}$ of mixed land use, ranging from forested, pristine areas in the upper reaches, to farmland along the lower reaches before draining into Lake Poygan and Lake Winnebago. The Upper Fox River drains primarily farmland prior to entering Lake Buttes Des Mortes and Lake Winnebago, where it joins the Wolf River. The lower Fox River, below Lake Winnebago, drains urban/industrial and agricultural areas of mainly clayey surficial deposits. The area between the outlet of Lake Winnebago (Neenah, Wis.) and the mouth at Green Bay has one of the highest concentrations of papermills in the world. The lower Fox River is regulated by Lake Winnebago and a series of hydroelectric dams; thus, the Fox River Fixed Site is not subject to extremes in stage. The river near the mouth is a wide, turbid, channelized shipping channel. At times, strong northeastern winds and seiches in the Green Bay cause a flow reversal in the river. Highest mean daily discharges for the study period occurred during April through July 1993. Water sampling did not begin at this site until October 1993. Twenty-six water samples were collected at the Fox River site during the study period (fig. 14).

Nitrate concentrations ranged from below the $0.05 \mathrm{mg} / \mathrm{L} \mathrm{MDL}$ to $2.1 \mathrm{mg} / \mathrm{L}$. The median concentration of $0.325 \mathrm{mg} / \mathrm{L}$ was similar to both the urban and forested NMC's and lower than the agricultural NMC (table 4).The highest nitrate concentrations were found in high-flow samples in spring 1994 and 1995. Concentrations were lowest during late summer and similar during the rest of the year. With reference to the other integrator sites, concentrations were similar to those at the Milwaukee River site, but significantly higher than those at the Menominee River site. Nitrate concentrations at the mouth of the Fox River Fixed Site were significantly lower than those at the East River and Tomorrow River, the indicator sites in the Fox River Basin.

Concentrations of total phosphorus ranged from 0.05 to $0.24 \mathrm{mg} / \mathrm{L}$; the median concentration of 0.115 $\mathrm{mg} / \mathrm{L}$ exceeds $0.10 \mathrm{mg} / \mathrm{L}$, the USEPA suggested limit for flowing waters. The NMC's (table 4) for agricultural and urban areas were similar to the median concentration at the mouth of the Fox River, whereas the NMC for forested areas was lower. The highest totalphosphorus concentrations were collected during periods of low flow. Measured high-flow concentrations from each event were similar. The data indicate a seasonality, with lowest total-phosphorus concentrations in the winter, and highest concentrations in the summer. Total-phosphorus concentrations were similar to those at the Milwaukee River integrator site, but significantly higher than those at the Menominee River integrator site. Total-phosphorus concentrations at the mouth of the Fox were significantly higher than those at the Tomorrow River Fixed Site, and lower than those at the East River Fixed Site.

Suspended-sediment concentration ranged from 6 to $241 \mathrm{mg} / \mathrm{L}$, with a median concentration of 27 $\mathrm{mg} / \mathrm{L}$. The highest measured concentration was in a sample collected during a high-flow event in April 1994. The lowest observed concentrations were generally found during low-flow sampling. There was no observed seasonal variability in suspended-sediment concentrations.

Concentrations of silica at the mouth of the Fox River ranged from 0.11 to $7.3 \mathrm{mg} / \mathrm{L}$; the median concentration was $1.30 \mathrm{mg} / \mathrm{L}$. The highest concentrations of silica were found in low-flow samples. A regression analysis did not indicate a significant correlation 
between streamflow and silica concentrations at this site. Silica concentrations at the mouth of the Fox River were significantly lower than those at the other integrator sites. The following factors might explain the lower concentrations: (1) Lake Winnebago functioning as a sink for silica, (2) diatoms in Lake Winnebago incorporating silica, (3) several reservoirs behind hydroelectric dams on the lower Wolf and lower Fox Rivers functioning as sinks, and (4) the surficial deposits below Lake Winnebago are primarily clayey, which contribute little silica to streams.

\section{Milwaukee River at Milwaukee, Wis.}

The Milwaukee River at Milwaukee, Wis., drains $1,803 \mathrm{~km}^{2}$, about 3 percent of the Western Lake Michigan Drainages Study Unit. The Fixed Site is in a city park, $10.9 \mathrm{~km}$ upstream from the mouth of the Milwaukee River. The river flows through agricultural and urban areas, including Milwaukee, Wis., the largest urban area in the Study Unit. Near the Fixed Site, the river flows over bedrock. A small dam is located just upstream from the sampling site. From late spring through early fall, the gates of the dam are usually closed; during this period, the river flows over a spillway. The rest of the year, the gates are open, and the river bypasses the spillway. During basin-wide rainstorms, the river is subject to an initial rapid change in stage due to increased runoff from areas of impermeable concrete and asphalt within the urban area, followed by a slower rise and longer peak stages due to slower runoff from the permeable agricultural areas upstream of Milwaukee. The highest mean daily discharges during the study period occurred in spring and early summer 1993. High-flow samples were collected during each of the growing seasons. In all, 49 water samples were collected at the Milwaukee River integrator site during the study period (fig. 15).

Nitrate concentrations ranged from below the 0.05 $\mathrm{mg} / \mathrm{L} \mathrm{MDL}$ to $2.8 \mathrm{mg} / \mathrm{L}$. The median concentration of $0.74 \mathrm{mg} / \mathrm{L}$ was similar to the agriculture NMC and higher than the urban NMC (table 4). The highest concentrations of nitrate were found in low-flow samples collected in January 1994 and 1995 . Five high-flow samples collected during the 1993 growing season had similar concentrations. These data indicate seasonality, with the highest nitrate concentrations occurring during the winter months. A combination of primarily groundwater recharge and the reduced uptake by dormant aquatic organisms during the winter months could account for the higher nitrate concentrations during this time of year. Nitrate concentrations were significantly higher than those at the other two integrator sites. Of the two indicator sites in the Milwaukee River Basin, only Lincoln Creek had a similar median nitrate concentration.

Total-phosphorus concentrations ranged from 0.03 to $0.43 \mathrm{mg} / \mathrm{L}$; the median concentration of $0.11 \mathrm{mg} / \mathrm{L}$ exceeds $0.10 \mathrm{mg} / \mathrm{L}$, the USEPA suggested limit for flowing waters. The median concentration was similar to both the urban and agricultural NMC's (table 4). The highest concentrations of total phosphorus generally were found during base-flow sampling in the summers of 1993 and 1994. Concentrations were lowest during the winter and highest during the growing season. Phosphorus concentrations at the Milwaukee River Fixed Site were similar to that at the mouth of the Fox River $(0.115 \mathrm{mg} / \mathrm{L})$ and significantly higher than those at the Menominee River $(0.02 \mathrm{mg} / \mathrm{L})$ Fixed Site. Of the two indicator sites within the Milwaukee River integrator basin, the North Branch Milwaukee River had similar concentrations, while Lincoln Creek, the urban indicator site, had significantly lower total-phosphorus concentrations.

Suspended-sediment concentration ranged from 6 to $323 \mathrm{mg} / \mathrm{L}$; the median concentration was $39 \mathrm{mg} / \mathrm{L}$. The highest suspended-sediment concentrations occurred in samples from two separate high-flow events and was associated with two of the higher sampled phosphorus concentrations. Suspended-sediment concentrations were similar to the mouth of the Fox River $(27 \mathrm{mg} / \mathrm{L})$ integrator site, but significantly higher than those at the Menominee River integrator site. The North Branch Milwaukee River agricultural indicator site suspended-sediment concentrations were higher than the Milwaukee River concentrations, while at Lincoln Creek, the urban indicator site, the suspended-sediment concentrations were considerably lower.

Silica concentrations at the Milwaukee River site ranged from 0.17 to $16 \mathrm{mg} / \mathrm{L}$; the median concentration was $6.40 \mathrm{mg} / \mathrm{L}$. The highest silica concentrations were found during base-flow sampling. These concentrations are similar to those at the Menominee River integrator site $(7.40 \mathrm{mg} / \mathrm{L})$, and significantly higher than that at the mouth of the Fox River $(1.3 \mathrm{mg} / \mathrm{L})$ integrator site. Silica concentrations at the Lincoln Creek Fixed Site where surficial deposits are clayey, were significantly lower than those at the Milwaukee River. Silica concentrations at the North Branch Milwaukee River Fixed 

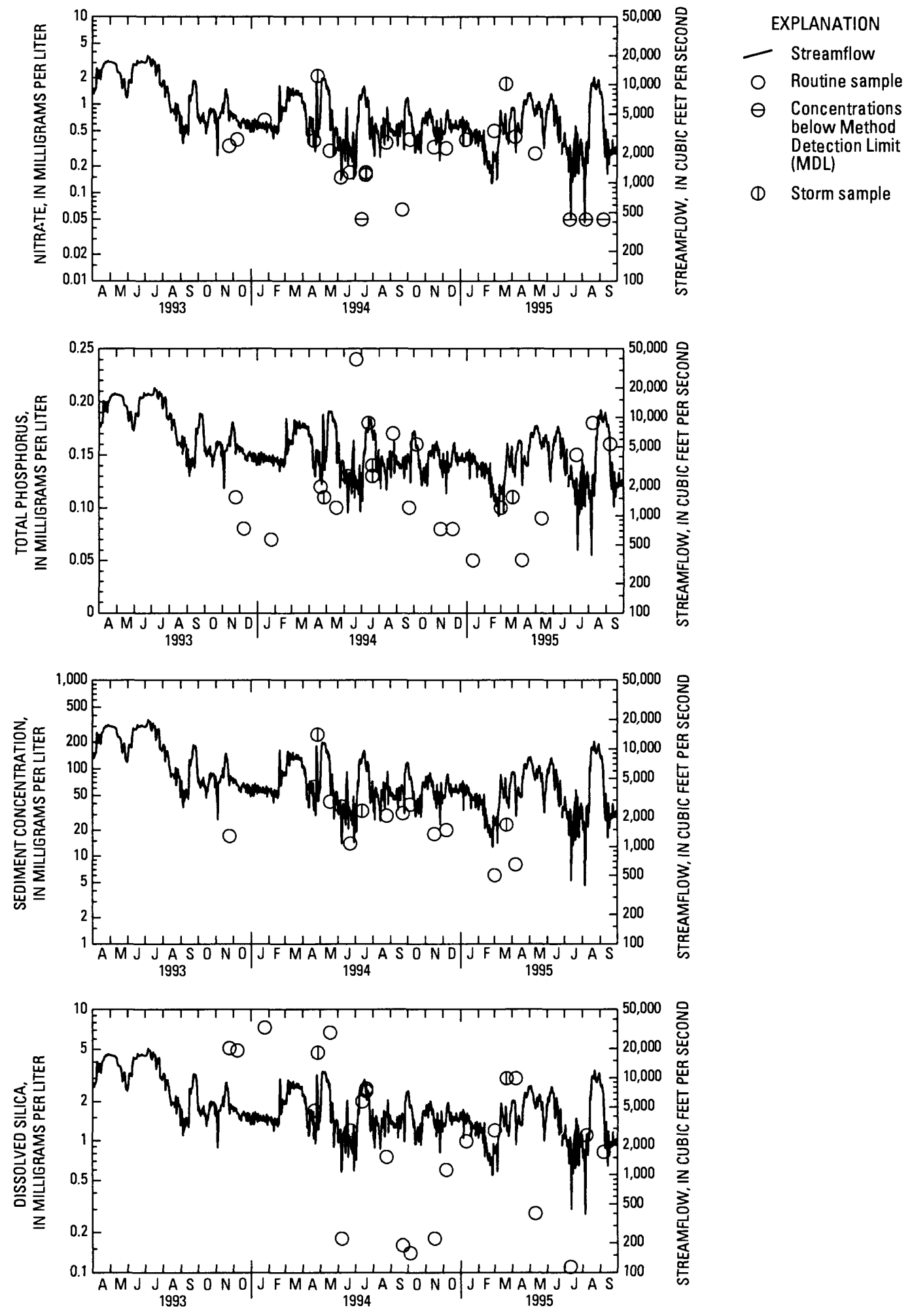

Figure 14. Streamflow and instantaneous concentrations of nitrate, total phosphorus, suspended sediment, and dissolved silica at the mouth of the Fox River at Green Bay, Wis. Streamflow data were collected at Fox River at Oil Tank Depot. 

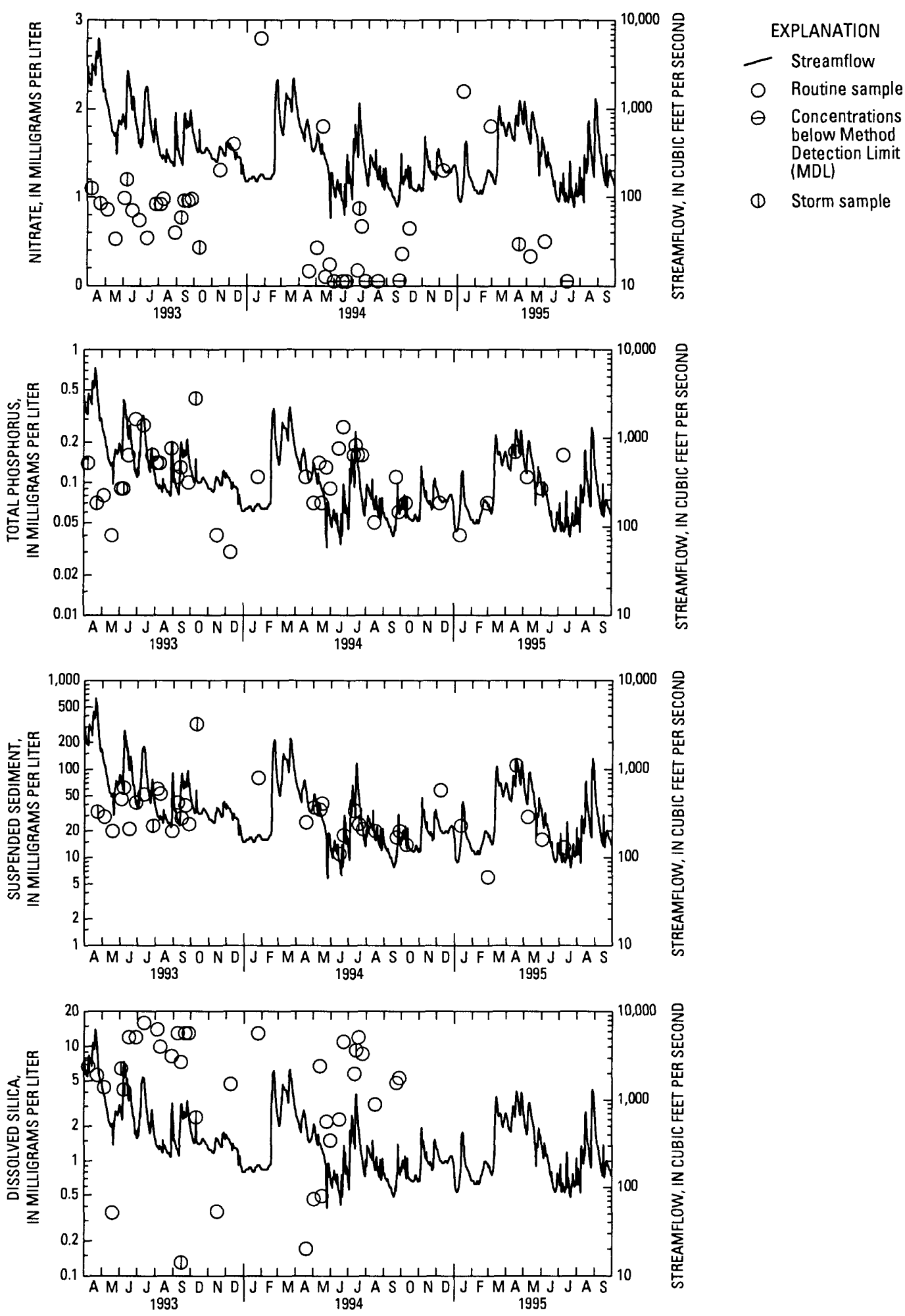

Figure 15. Streamflow and instantaneous concentrations of nitrate, total phosphorus, suspended sediment, and dissolved silica at the Milwaukee River at Milwaukee, Wis. 


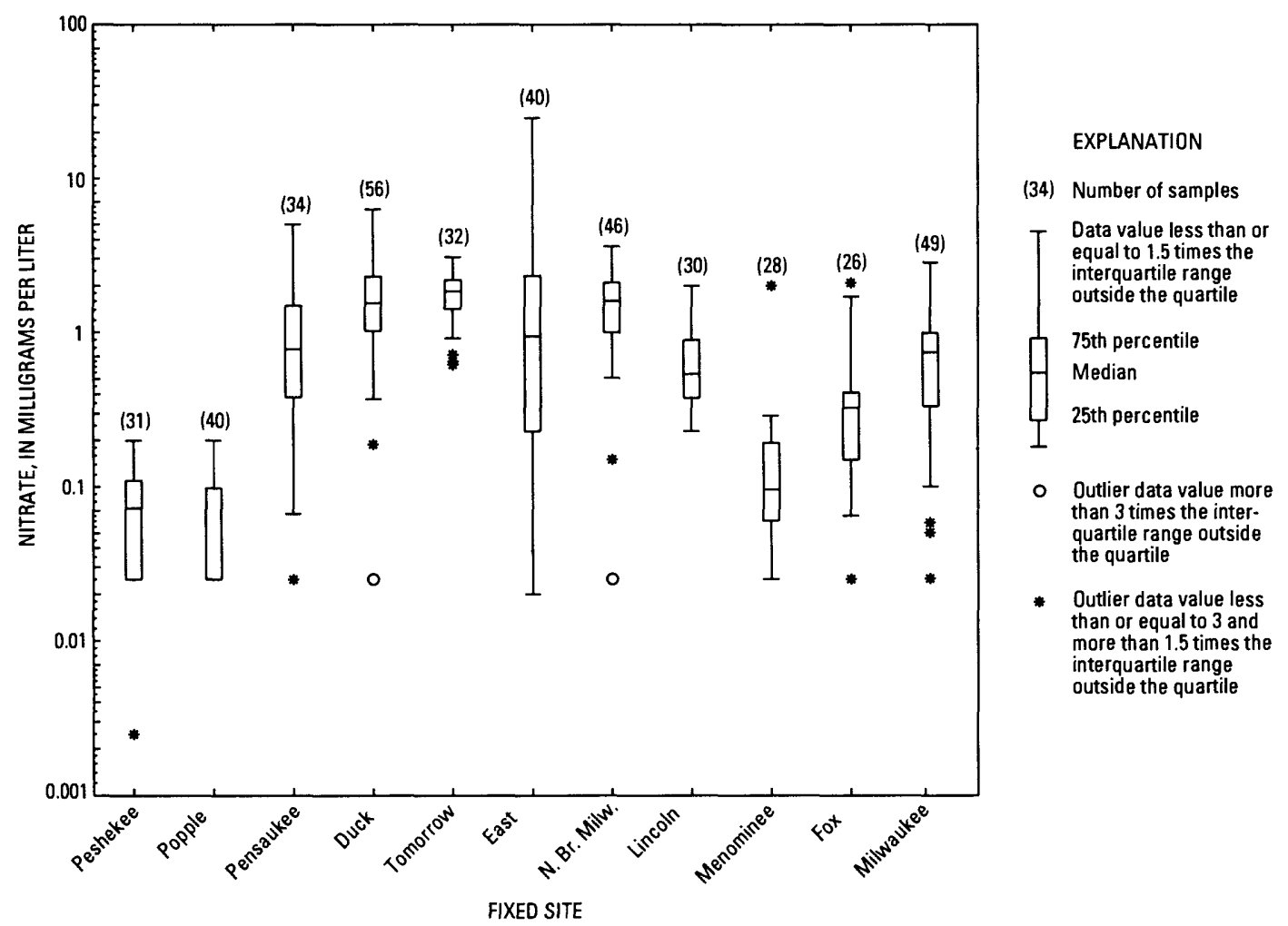

Figure 16. Distribution of concentrations of dissolved nitrite plus nitrate in streamwater samples collected at Fixed Sites in the Western Lake Michigan Drainages Study Unit, 1993-95.

Site, where surficial deposits are predominantly sandy, were significantly higher than those at this site.

\section{EFFECTS OF ANTHROPOGENIC AND NATURAL FACTORS ON WATER QUALITY}

Water quality at the Fixed Sites is affected in part by land use, surficial deposits, bedrock, and surface runoff. In this section, observations are presented that relate the water quality of the Fixed Sites to these factors, and compare and contrast the water quality at the Fixed Sites. The water-quality constituents discussed are: nitrate, total phosphorus, suspended sediment, dissolved solids, iron, calcium, potassium, silica, and fluoride.

Nitrogen and phosphorus are introduced into streams from agricultural fertilizers and manures, organic wastes in household and industrial effluents, atmospheric deposition, decomposition of organic material, and surficial deposits and bedrock (Robertson and Saad, 1996).
The highest median concentrations of nitrate were found at the two agricultural indicator sites with permeable surficial deposits, either sand and gravel or sandthe Tomorrow River $(1.85 \mathrm{mg} / \mathrm{L})$ and the North Branch Milwaukee (1.60 mg/L) (fig. 16). Both of these medians were more than twice the $0.72 \mathrm{mg} / \mathrm{L} \mathrm{NMC}$ for agricultural areas (table 4). The agricultural indicator sites with clayey surficial deposits had the next highest median nitrate concentrations-Duck Creek $(1.55 \mathrm{mg} / \mathrm{L})$ and East River $(0.95 \mathrm{mg} / \mathrm{L})$. The lowest median nitrate concentrations at an agricultural indicator site was at the Pensaukee River $(0.78 \mathrm{mg} / \mathrm{L})$, which has tightly packed loamy surficial deposits. The East River was the only Fixed Site where nitrate concentrations occasionally exceeded the $10 \mathrm{mg} / \mathrm{L}$ MCL. This concentration was exceeded in three samples collected during high-flow events in the growing season in 1994 and 1995. Median nitrate concentrations at the forested and urban indicator sites were at least an order of magnitude lower (Peshekee-0.073 mg/L, Popple-0.057 mg/L, and Lincoln Creek-0.54 mg/L) than those at the agricultural indicator sites. Nitrate concentrations at several of the 


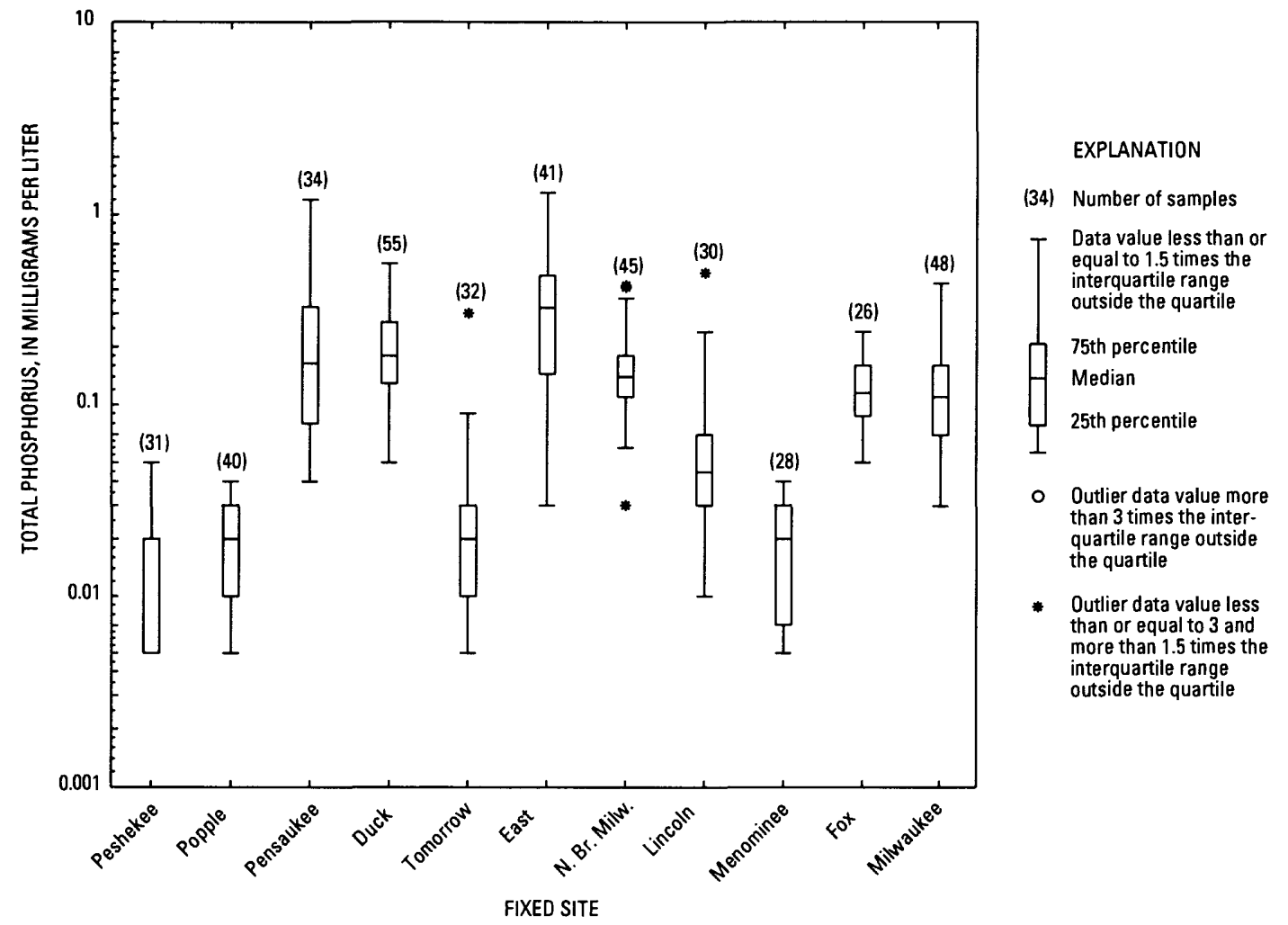

Figure 17. Distribution of concentrations of total phosphorus in streamwater samples collected at Fixed Sites in the Western Lake Michigan Drainages Study Unit, 1993-95.

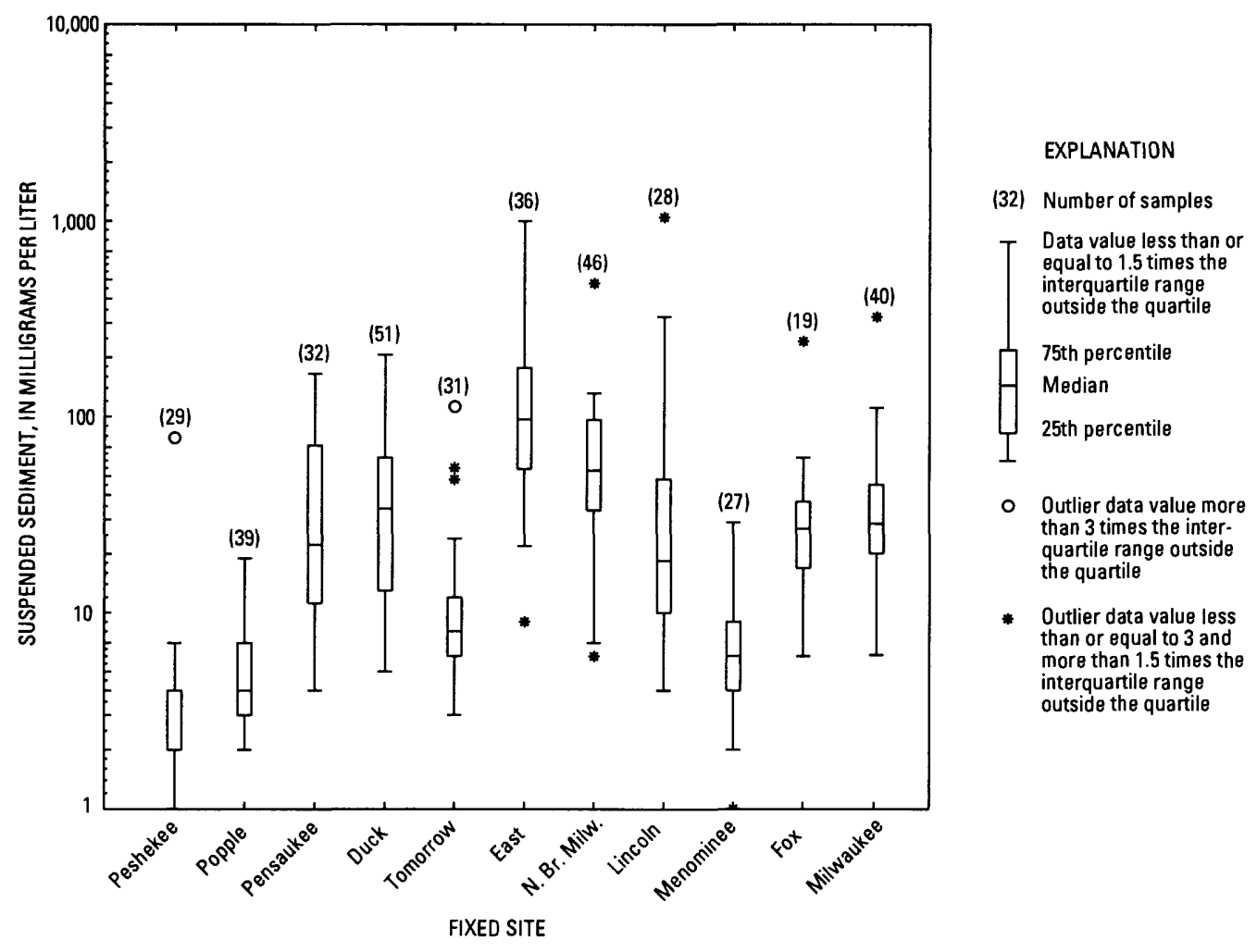

Figure 18. Distribution of concentrations of suspended sediment in streamwater samples collected at Fixed Sites in the Western Lake Michigan Drainages Study Unit, 1993-95. 
indicator sites (Peshekee, Popple, and Tomorrow) demonstrated a seasonal variability with higher concentrations during the winter months. A combination of ground-water recharge, colder temperatures, and dormant aquatic organisms could be the reason for higher nitrate concentrations in the winter. At the integrator sites, the median nitrate concentration was highest at the Milwaukee River $(0.74 \mathrm{mg} / \mathrm{L})$, followed by the mouth of the Fox River $(0.32 \mathrm{mg} / \mathrm{L})$ with extensive agriculture, and the Menominee River $(0.10 \mathrm{mg} / \mathrm{L})$ with predominantly forest, which had the lowest nitrate concentration. Data from the 1993-95 sampling indicate that nitrate concentrations at Fixed Sites in the Western Lake Michigan Drainages NAWQA Study Unit are affected most by a combination of land use and surficial deposits.

Total-phosphorus concentrations at the agricultural indicator sites-Pensaukee River, Duck Creek, North Branch Milwaukee River, and East River - were not significantly different; however, concentrations at the Tomorrow River were significantly lower than at the other agricultural indicator sites (fig. 17). The major difference between the Tomorrow River and the other agricultural indicator sites is the lower proportion of agricultural lands, and the higher proportion of groundwater discharge to the stream. The Tomorrow River Basin has a higher percentage of non-agricultural land than all other agricultural indicator sites. The two highest total-phosphorus concentrations were found at the East River $(1.3 \mathrm{mg} / \mathrm{L})$ and at the Pensaukee River $(1.2$ $\mathrm{mg} / \mathrm{L}$ ) and were collected from pools during a period of no flow. It is believed that high concentrations are caused by the leaching of phosphorus from the bottom sediments. Phosphorus concentrations in the stream decrease as the leached phosphorus is diluted by increased flows. Concentrations at the forested indicator sites were similar to one another and lower than the agricultural indicator sites. Total-phosphorus concentrations at the mouth of the Fox River $(0.115 \mathrm{mg} / \mathrm{L})$ were similar to those at the Milwaukee River $(0.11$ $\mathrm{mg} / \mathrm{L}$ ) integrator site, and concentrations at both sites were significantly higher than those at the Menominee River $(0.04 \mathrm{mg} / \mathrm{L})$ integrator site. Phosphorus concentrations at the Menominee River integrator site were similar to those at the Peshekee River and the Popple River indicator sites. These data indicate that totalphosphorus inputs from forests are generally lower than those from agricultural and urban lands. Generally, the highest phosphorus concentrations were found during the growing season at sites where agriculture was the predominant land use. Surface-water-quality data indicate that land use may be the factor that most affects total-phosphorus concentrations for the Western Lake Michigan Drainages Study Unit.

The highest median concentrations of suspended sediment were found at the agricultural indicator sites: East River ( $97 \mathrm{mg} / \mathrm{L})$, North Branch Milwaukee River (54 mg/L), and Duck Creek (34 mg/L) indicator sites. The lowest median concentrations were found at the forested indicator and integrator sites: Peshekee $(2.0 \mathrm{mg} / \mathrm{L})$, Popple $(4.0 \mathrm{mg} / \mathrm{L})$, and the Menominee River $(6.0 \mathrm{mg} / \mathrm{L})$. In general, higher suspended-sediment concentrations occurred during periods of high flow than during base flow. The highest suspendedsediment concentrations were found in a high-flow sample at Lincoln Creek $(1,050 \mathrm{mg} / \mathrm{L})$ and at the East River (1,000 mg/L) Fixed Site (fig. 18). Land use and streamflow appears to be the primary factors affecting suspended-sediment concentrations in the Western Lake Michigan Drainages Study Unit.

The highest median dissolved solid concentrations were found at the Duck Creek (464 mg/L) agricultural indicator site, and Lincoln Creek (464 mg/L), the urban indicator site (fig. 19). The median concentrations of dissolved solids at the Peshekee River (47 $\mathrm{mg} / \mathrm{L}$ ) Fixed Site were an order of magnitude lower than that at the other forested indicator (Popple River, $116 \mathrm{mg} / \mathrm{L}$ ) and integrator sites (Menominee River, $154 \mathrm{mg} / \mathrm{L}$ ) and also significantly lower than at all other sites. The Peshekee River Fixed Site was not significantly different from the Popple River in terms of concentrations of major ions except dissolved solids. The major environmental differences between the Popple River Basin and the Peshekee River Basin are the quantity and type of surficial deposits, and the proportion of forests and wetlands. The highest concentrations of dissolved solids at Lincoln Creek were found during samples collected during snowstorms in the winter of 1994-95, when the flow was slightly elevated; these data indicate that deicing compounds put on roadways by the street departments could possibly be a source of elevated dissolved-solids concentration.

Concentrations of dissolved fluoride at Lincoln Creek were significantly higher than all other Fixed Sites. The median fluoride concentration at Lincoln Creek $(0.50 \mathrm{mg} / \mathrm{L})$ was higher than all other indicator sites indicating that a potential source of fluoride could be the upstream discharge of treated water (fig. 20). The two integrator sites with urban drainage- 


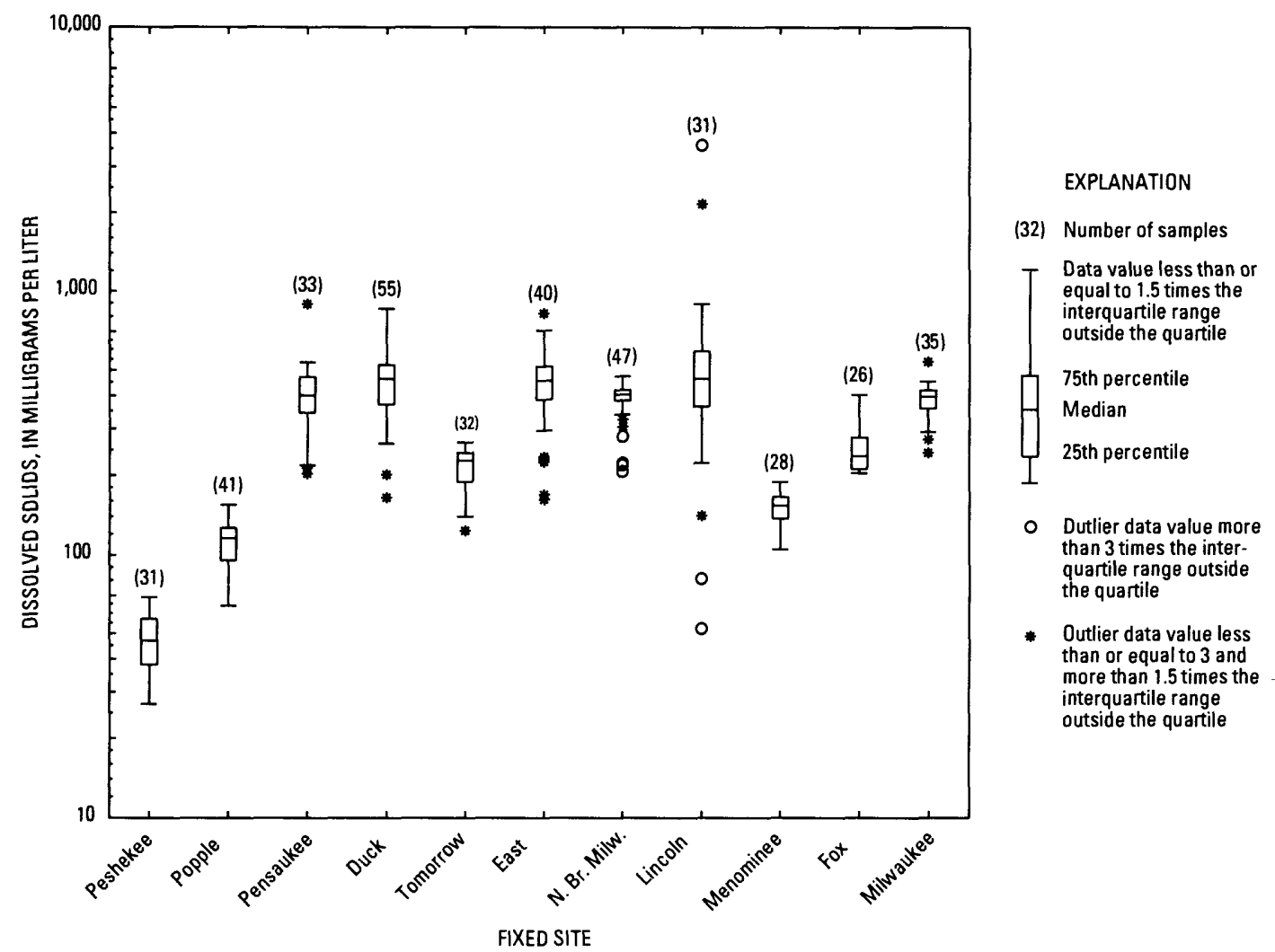

Figure 19. Distribution of concentrations of dissolved solids in streamwater samples collected at Fixed Sites in the Western Lake Michigan Drainages Study Unit, 1993-95.

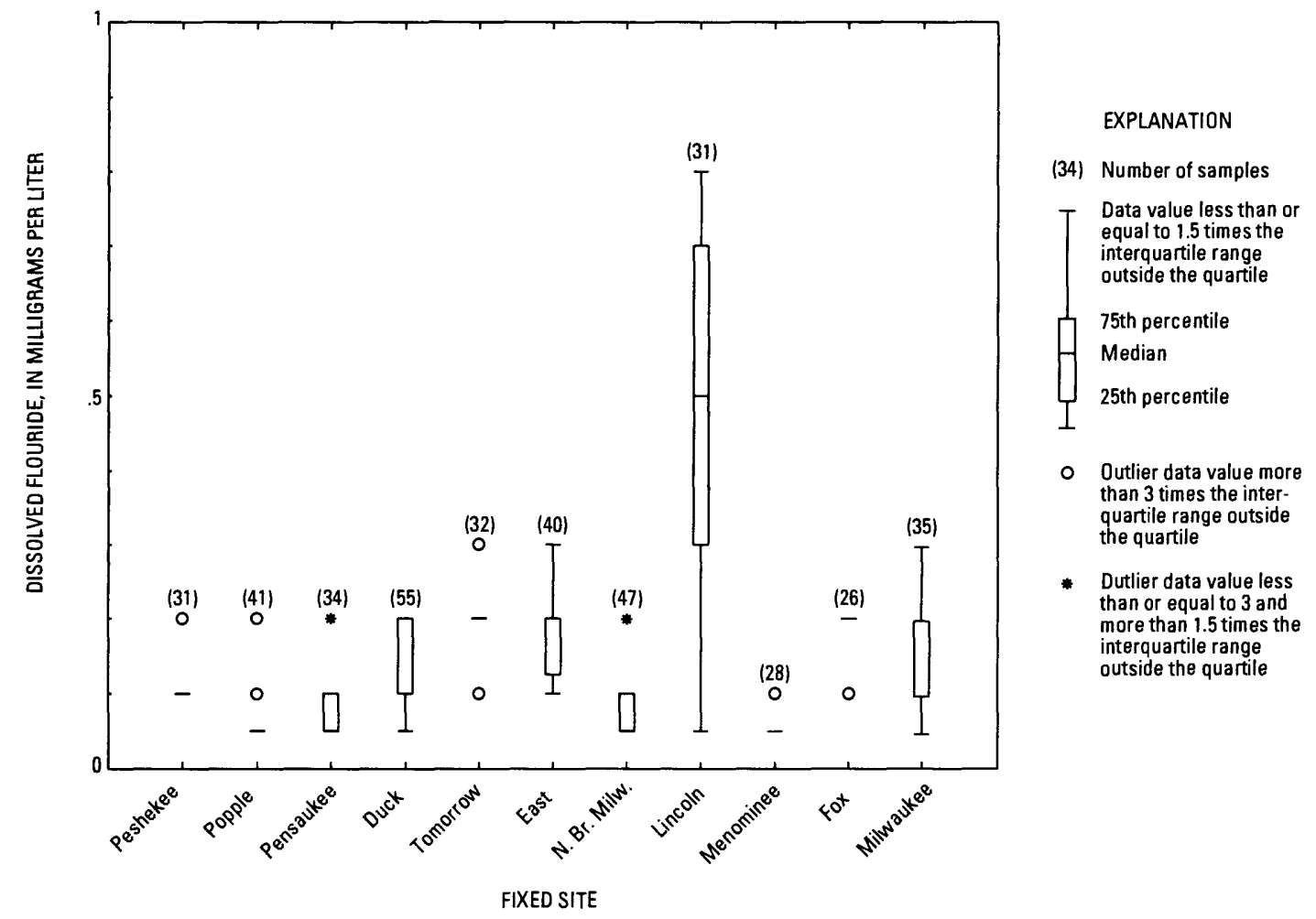

Figure 20. Distribution of concentrations of dissolved fluoride in streamwater samples collected at Fixed Sites in the Western Lake Michigan Drainages Study Unit, 1993-95. 


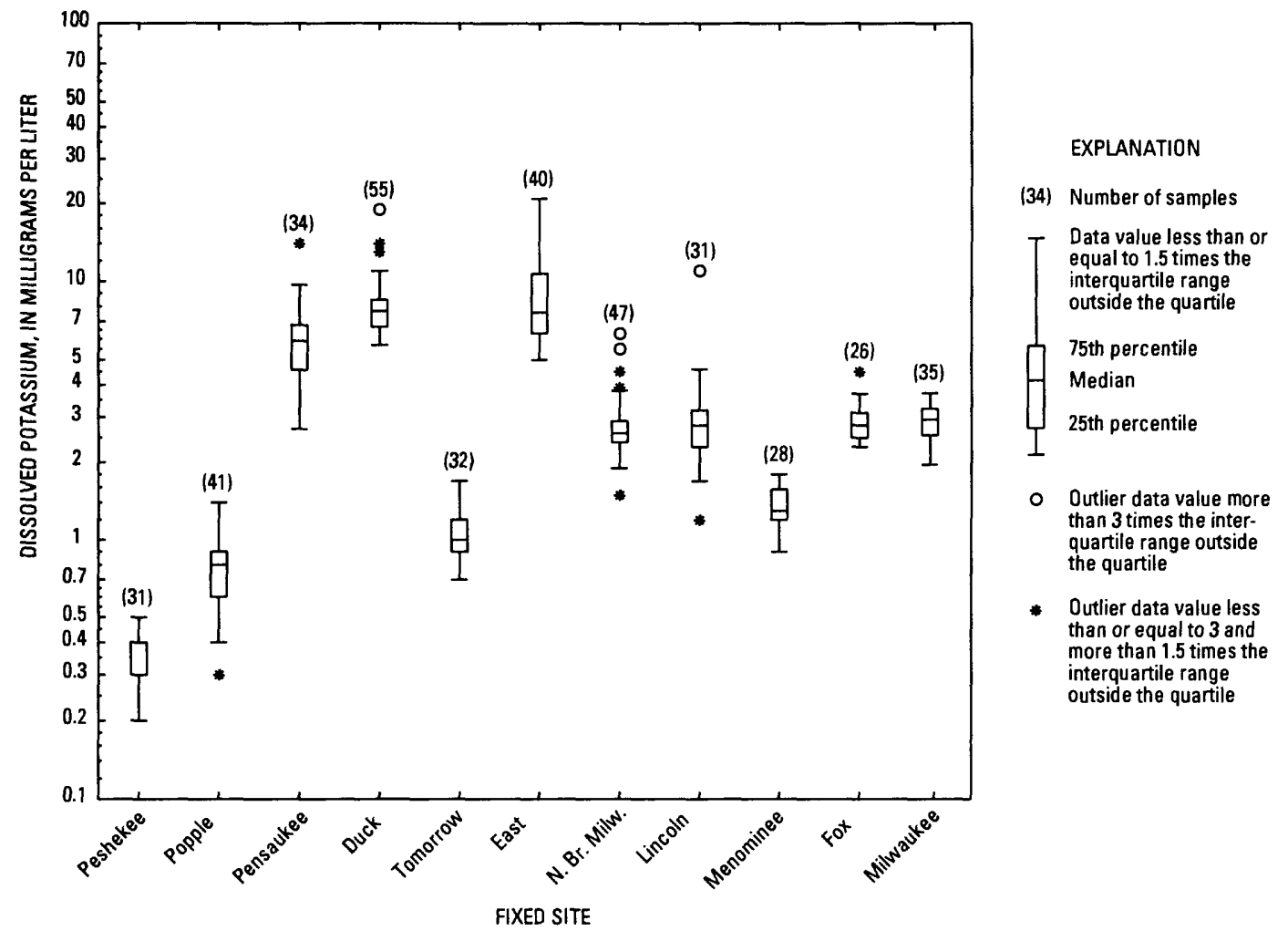

Figure 21. Distribution of concentrations of dissolved potassium in streamwater samples collected at Fixed Sites in the Western Lake Michigan Drainages Study Unit, 1993-95.

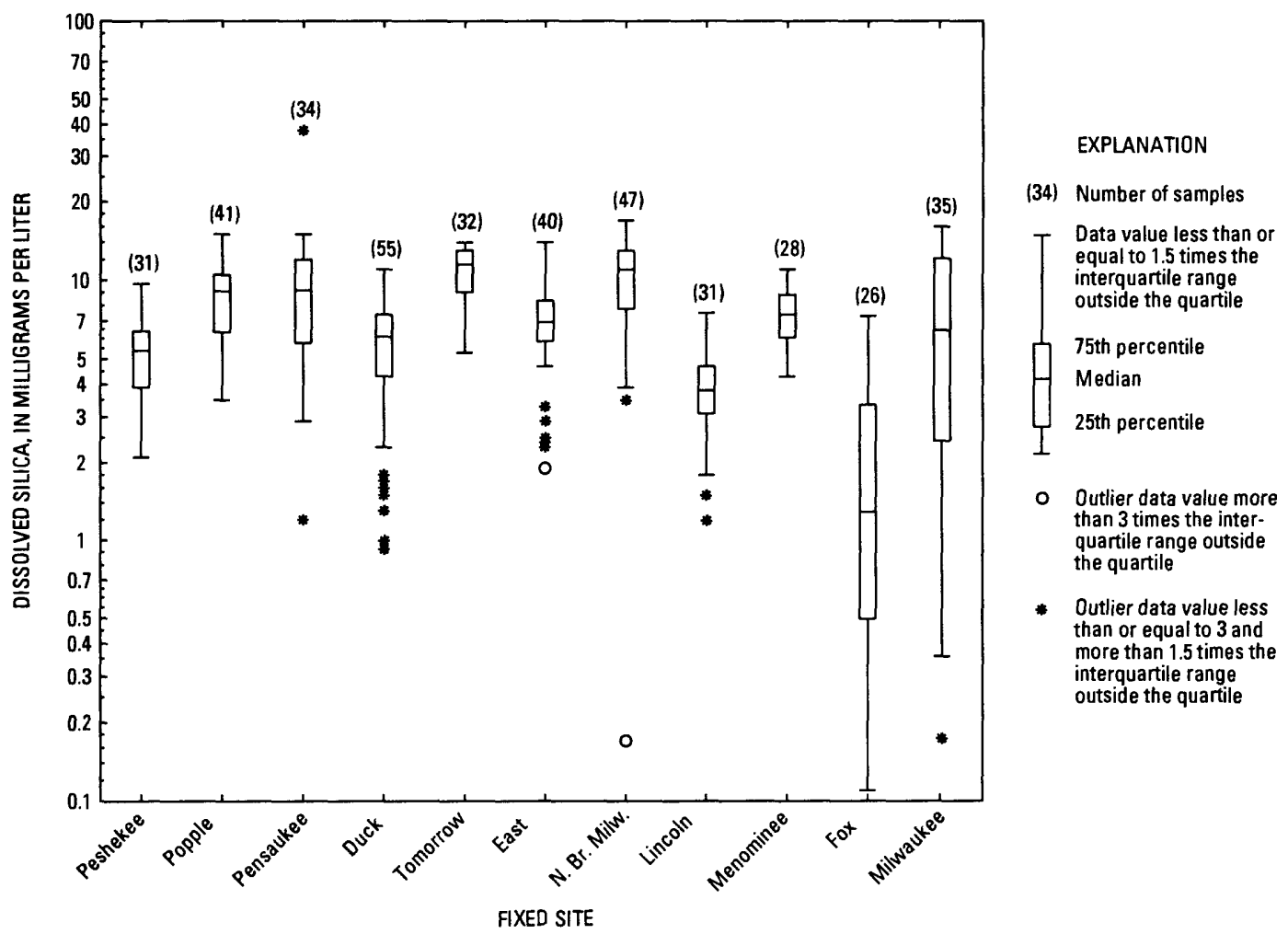

Figure 22. Distribution of concentrations of dissolved silica in streamwater samples collected at Fixed Sites in the Western Lake Michigan Drainages Study Unit, 1993-95. 
the Milwaukee River $(0.10 \mathrm{mg} / \mathrm{L})$ and the mouth of the Fox River $(0.20 \mathrm{mg} / \mathrm{L})$ - had significantly lower fluoride concentrations than Lincoln Creek, indicating that fluoride concentrations were more affected by urban land use within a small drainage than at urban integrator sites.

High concentrations of dissolved potassium were associated with clayey surficial deposits. Streamwater at the two indicator sites with clayey surficial deposits, Duck Creek and the East River, is turbid year round because of suspended clay particles, and these sites have the highest median potassium concentrations of the Fixed Sites. Median potassium concentrations at the East River (7.6 mg/L), and Duck Creek ( $7.7 \mathrm{mg} / \mathrm{L})$ were similar to those at the Pensaukee River, which is in an area of tightly packed loamy surficial deposits with high silica and clay contents, and the median values were significantly higher than those at the remaining Fixed Sites (fig. 21). Dissolved-potassium concentrations in streamwater in the Study Unit appear to be most affected by the surficial deposits present.

The pattern in dissolved-silica concentrations among the Fixed Sites indicate that silica concentrations were affected mostly by the distribution in surficial deposits within the Study Unit (fig. 22). The Tomorrow (11.5 mg/L), North Branch Milwaukee (11.0 mg/L), and Popple $(9.10 \mathrm{mg} / \mathrm{L})$ Rivers indicator sites were in areas with different land uses and bedrock types but similar sandy surficial deposits and had the highest concentrations. However, the Pensaukee River Fixed Site, which is underlain by loamy surficial deposits with high silica and clay content, yielded similarly high concentrations. The highest concentrations at the Pensaukee River site were found during periods of low flow, when ground water was the main source of streamflow. Median silica concentrations were similar at the Milwaukee River (6.40 $\mathrm{mg} / \mathrm{L})$ and Menominee River $(7.40 \mathrm{mg} / \mathrm{L})$ fixed integrator sites and significantly higher than that at the mouth of Fox River $(1.30 \mathrm{mg} / \mathrm{L})$ integrator site. The lower reaches of the Fox River below Lake Winnebago have primarily clayey surficial deposits, whereas the other integrator sites have more permeable surficial deposits, resulting in much lower concentrations of silica at the mouth of the Fox River than the other two integrator sites.

The median concentrations of iron for the Peshekee and Popple River Fixed Sites were significantly higher ( 3 to 4 times) than the median concentration at the nine other sites in the Study Unit (fig. 23). The Menominee River, the integrator site that includes the Popple and
Peshekee River in its drainage, had the third highest median iron concentrations of the Fixed Sites. The highest median concentrations of iron were found at the two forested sites underlain by igneous/metamorphic bedrock, the Popple $(320 \mu \mathrm{g} / \mathrm{L})$ and Peshekee River Fixed Sites $(350 \mu \mathrm{g} / \mathrm{L})$. The other Fixed Site underlain by igneous/metamorphic bedrock, the Tomorrow River $(66 \mu \mathrm{g} / \mathrm{L})$ had a significantly lower median concentration of iron. These data indicate that the source of elevated iron concentration could be either igneous/ metamorphic bedrock, forested land use, or a combination of the two.

Calcium concentrations within the Western Lake Michigan Drainages Study Unit appear to be most affected by the type of bedrock. The highest median concentrations of calcium were measured at the Duck Creek (81 mg/L), Pensaukee River (77 mg/L), East River (74 mg/L), and North Branch Milwaukee River (70 mg/L) Fixed Sites. Carbonate bedrock underlies the Pensaukee River, Duck Creek, North Branch Milwaukee River, and Milwaukee River Basins. Part of the East River headwaters flow over exposed carbonate bedrock. Concentrations at the remaining Fixed Sites, which have different bedrock types, were significantly lower. Highest calcium concentrations were found in the winter during periods of low-surface runoff, and the lowest concentrations were during periods of high flow. Thus, ground-water discharge appears to be a significant source of calcium at these sites.

\section{SUMMARY}

Streamflow was monitored continuously at 11 Fixed Sites in the Western Lake Michigan Drainages Study Unit from April 1993 through July 1995. During this period, surface-water samples were collected monthly. Additional samples were collected annually at each of the Fixed Sites during storms. Of the 11 Fixed Sites, 8 sites were selected to represent conditions in 8 areas with relatively homogeneous land use, surficial deposits, and bedrock. The three remaining Fixed Sites were in watersheds that integrate the effects of a variety of land uses, surficial deposits, and bedrock types, and are near the mouths of major rivers, to represent a large part of the total river flow from the Study Unit to Green Bay and western Lake Michigan. Samples were collected by use of standard National Water-Quality Assessment protocols and were analyzed at the National Water-Quality Laboratory. Statistical techniques were used to determine whether selected constit- 


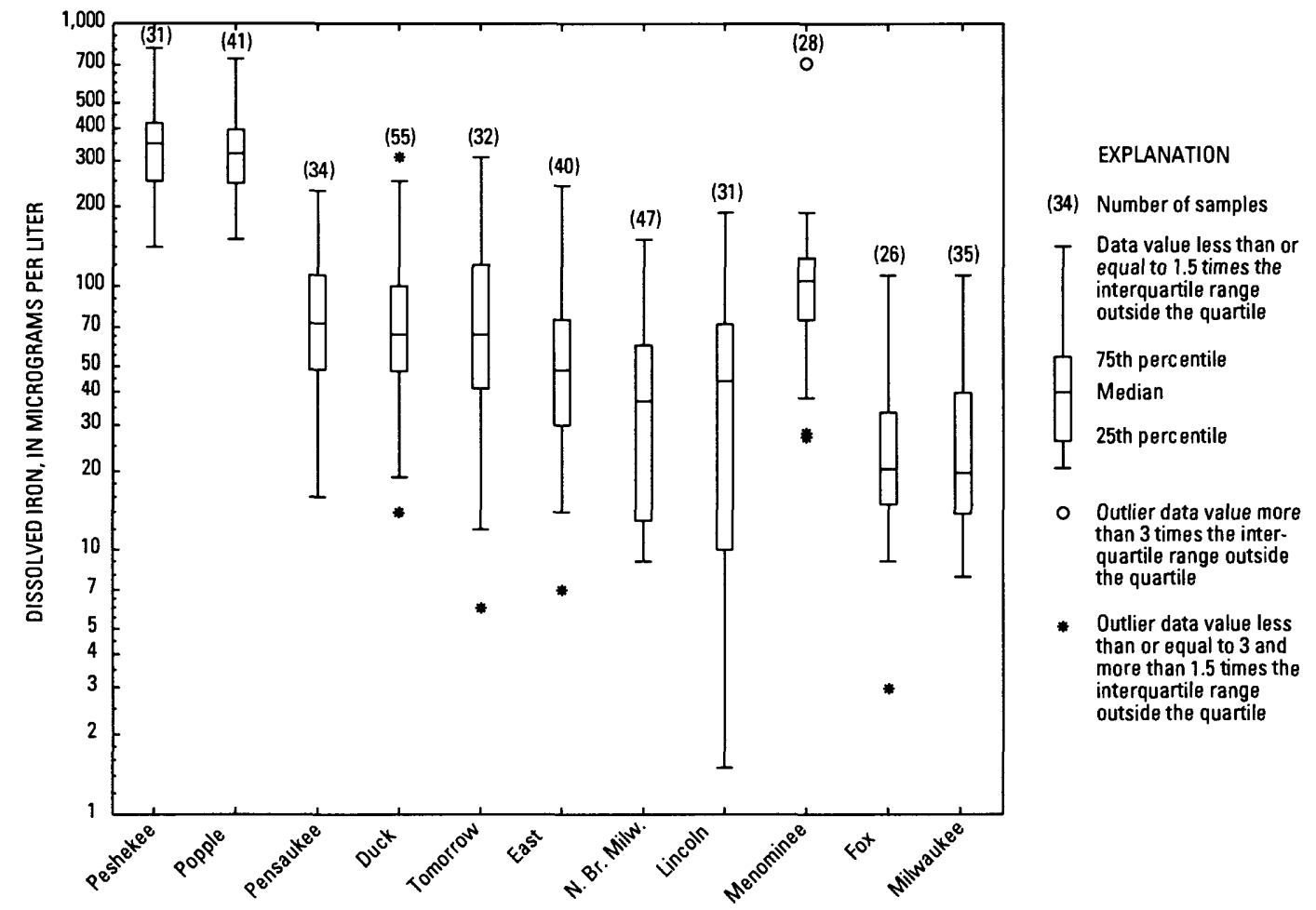

FIXED SITE

Figure 23. Distribution of concentrations of dissolved iron in streamwater samples collected at Fixed Sites in the Western Lake Michigan Drainages Study Unit, 1993-95.

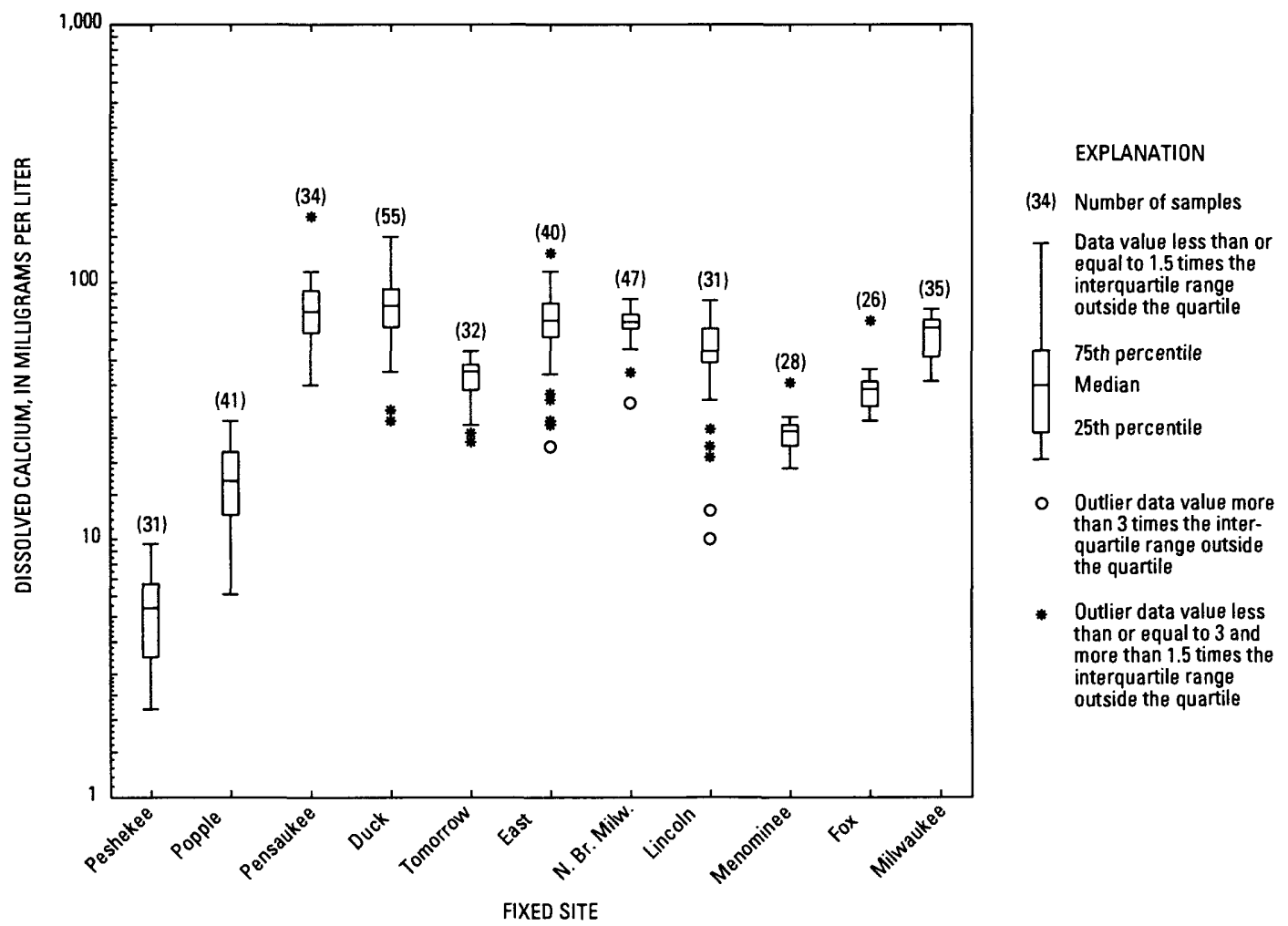

Figure 24. Distribution of concentrations of dissolved calcium in streamwater samples collected at Fixed Sites in the Western Lake Michigan Drainages, 1993-95. 
uents could be used to represent the suite of nutrients and major ions, and whether differences in concentrations between sites were significant. Precipitation patterns within the Study Unit during the study period were compared to long-term averages and analyzed for relationships to water quality.

Median concentrations of nitrate at the forested sites were below the National Median Concentration (NMC) for forested areas, and median nitrate concentrations at urban Fixed Sites were similar to the urban NMC. Median nitrate concentrations at the Tomorrow River, North Branch Milwaukee River, and Duck Creek Fixed Sites were twice the agricultural NMC, but median concentrations at the remaining agricultural indicator sites were similar to the NMC for agricultural areas. Nitrate concentrations at the East River exceeded $10 \mathrm{mg} / \mathrm{L}$, the United States Environmental Protection Agency maximum contaminant level for drinking water, during three periods of high flow during the 1994 and 1995 growing seasons.

Median total-phosphorus concentrations at the forested indicator sites were below the NMC. Tomorrow River was the only agricultural indicator site where the median total-phosphorus concentration was less than the agricultural NMC; median total-phosphorus concentrations at the remaining agricultural Fixed Sites were similar to the agricultural NMC. Median total-phosphorus concentrations at all the agricultural indicator sites, with the exception of the Tomorrow River, exceeded the USEPA suggested total-phosphorus concentration for flowing water. A larger percentage of non-agricultural lands (forests) within the Tomorrow River watershed is the major difference between the Tomorrow River site and the other agricultural indicator sites. Median totalphosphorus concentration at Lincoln Creek was less than the urban NMC. Median concentrations for both nitrate and total phosphorus at the mouth of the Fox and Milwaukee River integrator sites were similar to the NMC for the dominant land use within their basins, but the median concentrations for both constituents were lower than the NMC for the dominant land use (forested) within the Menominee River Basin. These data indicate that land use may be the primary factor affecting total-phosphorus concentrations and that a combination of land use and permeable surficial deposits may have the greatest effect on nitrate concentrations in this Study Unit.

The primary factors affecting concentrations of dissolved solids, fluoride, potassium, silica, iron, and calcium were surficial deposits and bedrock type. Concen- trations of dissolved solids, silica, and calcium generally were higher when ground-water discharge to the stream at the Fixed Site was significant. Potassium concentrations were highest in areas of clay-dominated surficial deposits, silica concentration highest in areas of sandy surficial deposits, iron concentration highest in areas of igneous bedrock and forested land use, and calcium concentrations were highest in areas of carbonate bedrock. Increased fluoride concentrations seems to be related to urban land use; the highest median fluoride concentration was found at an urban site that receives much of its flow during dry periods from treated water.

\section{REFERENCES CITED}

Anderson, J.R., Hardy, E.E., Roach, J.T., and Witmer, R.E., 1976, A land use and land cover classification system for use with remote sensor data: U.S. Geological Survey Professional Paper 964, 28 p.

Edwards, T.K., and Glysson, G.D., 1988, Field methods for measurement of fluvial sediment: U.S. Geological Survey Open-File Report 86-531, 118 p.

Finney, Michael, 1995, Watershed restoration activities of the Oneida Tribe of Indians of Wisconsin [abs.], in National Water-Quality Assessment Program, Western Lake Michigan Drainages-Summaries of Liaison Committee Meeting, Green Bay, Wis., March 28-29, 1995: U.S. Geological Survey Open-File Report 95$163,43 \mathrm{p}$.

Fishman, M.J., and Friedman, L.C., 1989, Methods for determination of inorganic substances in water and fluvial sediments: U.S. Geological Survey Techniques for Water-Resources Investigations, book 5, chap. A1, $545 \mathrm{p}$.

Fitzgerald, S.A., 1997, Results of quality-control sampling of water, bed sediment, and tissue in the Western Lake Michigan Drainages Study Unit of the National WaterQuality Assessment Program: U.S. Geological Survey Water-Resources Investigations Report 97-4148, 24 p.

Hem, J.D., 1985, Study and interpretation of the chemical characteristics of natural water (3rd ed.): U.S. Geological Survey Water-Supply Paper 2254, $263 \mathrm{p}$.

Hirsch, R.M., Alley, W.M., and Wilber, W.G., 1988, Concepts for a National Water-Quality Assessment Program: U.S. Geological Survey Circular 1021, 42 p.

Holmstrom, B.K., Kammerer, P.A., Jr., and Ellefson, B.R., 1994, Water Resources Data, Wisconsin, water year 1994, vol. 1, St. Lawrence River Basin: U.S. Geological Survey Water-Data Report WI-94-1, 406 p.

Hooper, R.P., Goolsby, D.A., Rickert, D.A., and MacKenzie, S.W., 1997, NASQAN a program to monitor the water quality of the Nations large rivers: U.S. Geological Survey Fact Sheet FS-055-97, 6 p. 
Iman, R.L., and Conover, W.J., 1983, A modern approach to statistics: New York, John Wiley and Sons, 497 p.

Robertson, D.M., 1996, Sources and transport of phosphorus in the Western Lake Michigan Drainages: U.S. Geological Survey Fact Sheet FS-208-96, 4 p.

Robertson, D.M., and Saad, D.A.,1995, Environmental factors used to subdivide the Western Lake Michigan Drainages into Relatively Homogeneous Units for water-quality site selection: U.S. Geological Survey Fact Sheet FS-220-95, 4 p.

1996, Water Quality Assessment of the Western Lake Michigan Drainages-Analysis of available information on nutrients and suspended sediment, water years 1971-90: U.S. Geological Survey Water-Resources Investigations Report 96-4012, 165 p.

Saad, D.A., 1994, Nitrate in ground water in the Western Lake Michigan Drainage Basin, Wisconsin and Michigan: U.S. Geological Survey Fact Sheet FS-070-94, $2 \mathrm{p}$.

SAS Institute Inc., 1990, SAS/STAT Users Guide, version 6 (4th ed.): Cary, N.C., SAS Institute [variously paginated].

Shelton, L.R., 1994, Field guide for collecting and processing stream-water samples for the National Water-Quality Assessment Program: U.S. Geological Survey OpenFile Report 94-455, $42 \mathrm{p}$.

Smith, R.A., Alexander, R.B., and Lanfear, K.J., 1993, Stream water quality in the conterminous United States-Status and trends of selected indicators during the 1980's: in Paulson, R.W. and others, Compilers, National Water Summary 1990-91: U.S. Geological Survey Water-Supply Paper 2400, p. 111-140.

Stewart, J.S., 1994, Assessment of alternative methods for stratifying Landsat TM data to improve land cover classification accuracy across areas with physiographic variation: University of Wisconsin-Madison, Master's thesis, $159 \mathrm{p}$.
Stewart, J.S., 1995, Developing a current land-cover data layer for the Western Lake Michigan Drainages [abs]: in Peters, C.A., National Water-Quality Assessment Program, Western Lake Michigan Drainages, Summaries of Liaison Committee Meeting, Green Bay, Wisconsin, March 28-29, 1995: U.S. Geological Survey Open-File report 95-163, $11 \mathrm{p}$.

Sullivan, D.J., Peterson, E.M., and Richards, K.D., 1995, Environmental settings of Fixed Sites in the Western Lake Michigan Drainages, Michigan and Wisconsin, U.S. Geological Survey Water-Resources Investigations Report 95-4211-A, 30 p.

Sullivan, D.J., and Richards, K.D., 1996, Pesticides in streams in Western Lake Michigan Drainages, Wisconsin and Michigan, 1993-95: U.S. Geological Survey Fact Sheet FS-107-96, 4 p.

U.S. Department of Agriculture, Farm Service Agency, 1997, Agricultural resource conservation program, 2-CRP Revision 3.

Ward, J.R., and Harr, C.A., 1990, Methods for collection and processing of surface-water and bed-material samples for physical and chemical analysis: U.S. Geological Survey Open-File Report 90-140, 71 p.

Wisconsin Department of Agriculture, Trade and Consumer Protection, 1966, 1975, 1985, 1994, 1995, 1996, Wisconsin agricultural statistics: Published annually.

Wisconsin Department of Natural Resources, 1994, Wisconsin Water-Quality Assessment Report to Congress, 1994: Wisconsin Department of Natural Resources, Publ-WR254-94-REV, 324 p.

U.S. Department of Commerce, 1991, 1990 Census of population and housing, summary population and housing characteristics, Wisconsin: Bureau of the Census, CPH-1-51, $370 \mathrm{p}$. 